\title{
$\mathrm{BMC}$
}

\section{Clinical Pathology}

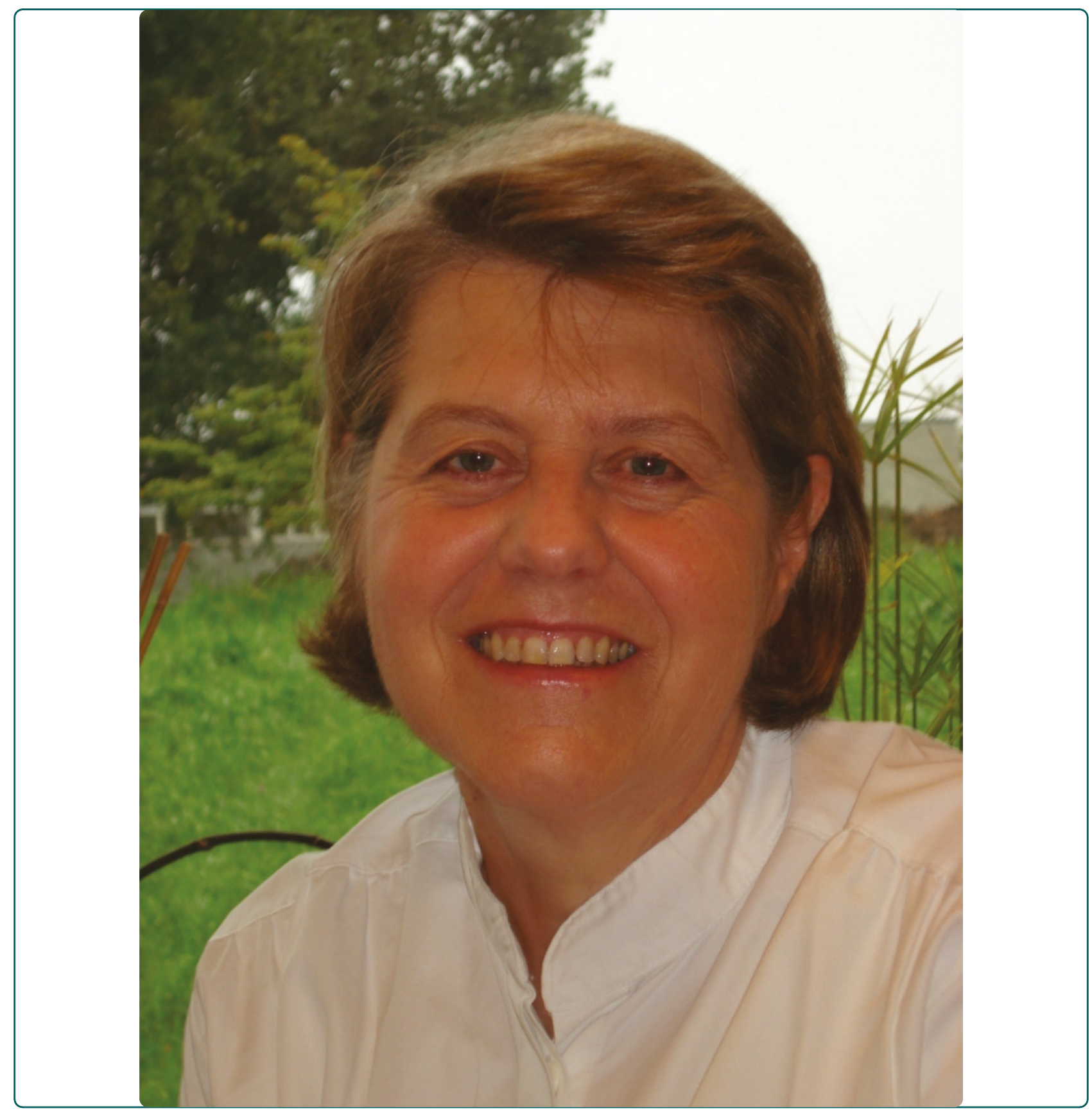

\section{Effects of different centrifugation conditions on clinical chemistry and Immunology test results}

Minder et al. 


\title{
Effects of different centrifugation conditions on clinical chemistry and Immunology test results
}

\author{
Elisabeth I Minder ${ }^{1 *}$, Adrian Schibli², Dagmar Mahrer ${ }^{1}$, Predrag Nesic ${ }^{1}$ and Kathrin Plüer ${ }^{1}$
}

\begin{abstract}
Background: The effect of centrifugation time of heparinized blood samples on clinical chemistry and immunology results has rarely been studied. WHO guideline proposed a 15 min centrifugation time without citing any scientific publications. The centrifugation time has a considerable impact on the turn-around-time.

Methods: We investigated 74 parameters in samples from 44 patients on a Roche Cobas 6000 system, to see whether there was a statistical significant difference in the test results among specimens centrifuged at $2180 \mathrm{~g}$ for $15 \mathrm{~min}$, at $2180 \mathrm{~g}$ for $10 \mathrm{~min}$ or at $1870 \mathrm{~g}$ for $7 \mathrm{~min}$, respectively. Two tubes with different plasma separators (both Greiner Bio-One) were used for each centrifugation condition. Statistical comparisons were made by Deming fit.

Results: Tubes with different separators showed identical results in all parameters. Likewise, excellent correlations were found among tubes to which different centrifugation conditions were applied. Fifty percent of the slopes lay between 0.99 and 1.01. Only 3.6 percent of the statistical tests results fell outside the significance level of $p<0.05$, which was less than the expected $5 \%$. This suggests that the outliers are the result of random variation and the large number of statistical tests performed. Further, we found that our data are sufficient not to miss a biased test (beta error) with a probability of 0.10 to 0.05 in most parameters.
\end{abstract}

Conclusion: A centrifugation time of either 7 or 10 min provided identical test results compared to the time of 15 min as proposed by WHO under the conditions used in our study.

\section{Background}

Most clinical chemistry analyses in blood samples require centrifugation prior to the analyses in order to separate blood cells and other solid components such as fibrin from serum or plasma. Although this pre-analytical procedure is performed innumerable times every day in all medical laboratories worldwide, the influence of centrifugation on laboratory results has only rarely and only recently been investigated [1-3]. Indeed, the information contained in the publications and guidelines from scientific societies rely either on expert opinions or recommendations from the manufacturers rather than on published scientific investigations [4-6].

The separation efficacy of the centrifugation process depends on four variables, the centrifugation time, the relative centrifugation force (RCF), the length of blood collection tubes and the temperature. The length of

\footnotetext{
* Correspondence: elisabeth.minder@triemli.zuerich.ch

'Stadtspital Triemli, Central laboratory Birmensdorferstrasse 497 CH-8063

Zürich Switzerland

Full list of author information is available at the end of the article
}

tubes defines the volume of plasma or serum that is required for the analyses and is usually given. The RCF is limited by the resistance of the tubes and the blood components to the gravity and the technical limits of the centrifuge and its rotor. Variations in temperature are limited by stability of analytes. Thus, only the centrifugation time can be easily varied to achieve the desired quality of the specimen for the subsequent analyses.

The above cited guidelines proposed a centrifugation time of at least $10 \mathrm{~min}$ for serum and of $15 \mathrm{~min}$ for plasma with a RCF between 2000 and $3000 \mathrm{~g}$ [6]. Hospital laboratories serving emergency departments, intensive care units and busy outpatient clinics strive for minimizing their turn-around-times (TAT)[2]. The centrifugation step consumes a large portion of the preanalytical time in the laboratory and therefore a considerable amount of the total TAT. A reduction in this time-consuming step is therefore in the focus. Indeed, centrifugation times as short as $30 \mathrm{sec}$ have been used under certain circumstances, but no formal evaluations of such procedures have been published $[7,8]$. 
Another step to reduce TAT is the use of heparinized plasma instead of serum. Serum samples from fully anticoagulated patients may continue to coagulate for several hours after blood draw, which may affect the analytical process. Small particles of fibrin clots may block pipetting needles of the analyzers or interfere with chemiluminescence assays. Although collection tubes with special additives to reduce coagulation time to a few minutes, have been developed [3], yet we found that the coagulation process in specimens of fully anticoagulated patients is not completed after $15 \mathrm{~min}$ (E. Minder, unpublished observations). An alternative is to use tubes containing lithium heparinate which prevents coagulation and allows centrifugation immediately after the arrival of the tubes in the laboratory. Heparinized plasma instead of serum can be used for most clinical chemistry and many immunological analyses today, depending on the analytical platform and the reagents used.

Gels, also called separators, interpose between the cellular and fluid phase of the blood specimen during centrifugation and act as a barrier thereafter preventing the diffusion of analytes between the two phases. The gel barrier is formed only after adequate centrifugation time and force. An incomplete gel formation may interfere with certain analyses [9]. Separator gels from different manufacturers may have different compositions and therefore behave differently under identical centrifugation conditions, which could results in differences in test results.

In this report, we investigated the effect of distinct centrifugation conditions on a broad range of routine clinical chemistry and immunology analyses. These conditions included the centrifugation time pro-posed by the WHO-guidelines and two shorter ones of 10 and 7 min, respectively. We also examined the possible effect of two different gel separators on the same set of laboratory parameters.

\section{Methods}

\subsection{Patients}

Consecutive patients admitted to our medical wards between September and October 2009 were asked to provide six additional tubes for the study during regular blood draws. Exclusion criterion was a known or suspected anemia.

\subsection{Blood sampling and centrifugation}

Phlebotomy was performed using a butterfly needle (Greiner Bio-One reference number 450085). Between the regular drawing and the study samples, a $5 \mathrm{ml} \mathrm{Z} \mathrm{no}$ additive Vacuette ${ }^{\mathbb{B}}$ (Greiner Bio-One reference number 456202) was filled and discarded. Then, three evacuated tubes with gel separator $(5 \mathrm{ml}$ Lithium Heparin Sep 13 $\times 100 \mathrm{~mm}$ Vacuette ${ }^{\circledR}$ Premium, Greiner Bio-One reference number 456083, available in Europe, called 'tube 11 ' hereafter) and three evacuated tubes with gel separator $\left(5 \mathrm{ml}\right.$ Lithium Heparin Sep $13 \times 100 \mathrm{~mm}$ Vacuette ${ }^{\circledR}$, Greiner Bio-One reference number 456087 RP, available in USA, called 'tube 22' hereafter) were filled with venous blood. After gently inverting the tubes eight times, they were sent immediately to the laboratory by a pneumatic tube system and centrifuged within one hour after blood draw on a Rotixa 50 RS Hettich centrifuge equipped with a swing-out bucket rotor. The three centrifugation conditions were as follows: acceleration time of $32 \mathrm{sec}$ (included in the overall centrifugation time), deceleration time of $32 \mathrm{sec}$ (after centrifugation) and temperature at $+15^{\circ} \mathrm{C}$ in all three conditions; condition 1: centrifugation time $15 \mathrm{~min}$ at $2180 \mathrm{~g}$ or $32,700 \mathrm{gmin}$, condition 2: $10 \mathrm{~min}$ at $2180 \mathrm{~g}$ or 21,800 gmin and condition 3: $7 \mathrm{~min}$ at $1870 \mathrm{~g}$ or 13,090 gmin, respectively.

The sequence of the tubes during blood draw was registered. To avoid any influence from this sequence, a pre-specified randomization protocol was used to allocate the tubes to the different centrifugation conditions. A collection of samples from at least 40 patients would attain sufficient statistical power and thus specimens from 47 patients were collected. Analyses were performed only if all six tubes collected per patient were of sufficient quality, i.e. without visible hemolysis or lipidemia. Tubes from 44 patients met the criteria and were therefore investigated. For statistical reasons, a patient was included only once.

\subsection{Analyses of samples}

Certified medical technicians with several years of working experience performed all laboratory procedures. Immediately after centrifugation, the samples were analyzed on a COBAS 6000 analyzer (Roche Diagnostics, Rotkreuz, Switzerland) equipped with the core unit cu 150 (Part number 727-0189), the modules c 501 (part number 727-2983) and e 601 (part number 727-2984). The instrument was equipped with standard reagents, calibrators and quality control material manufactured by Roche Diagnostics (Rotkreuz, Switzerland). Seventy-four different tests as listed in table 1 were performed on each tube, giving rise to a total of 444 results per patient. The analyses were performed within 3 hours after the sample collection with an exception of the immunological parameters for infectious diseases, which were examined within 48 hours. All tubes were stored at $4^{\circ} \mathrm{C}$ before analyses.

This study was initiated by the investigators; the costs of the study were covered by two companies (see acknowledgments). The study was approved by the institutional review board (Kantonale Ethikkommission Zürich), and the participating patients gave their written 
Table 1 All test analyzed, their control values and further data used for estimation of the beta error.

\begin{tabular}{|c|c|c|c|c|c|c|c|c|c|c|c|c|c|c|c|}
\hline Test & Abbreviation & $\begin{array}{c}\mathrm{QC} \\
\text { target } \\
\text { value }\end{array}$ & unit & $\mathrm{n}$ & mean & SD & CV & $\begin{array}{l}\text { Maximal } \\
\text { error } \\
\text { (CLIA) }\end{array}$ & $\begin{array}{l}\text { lowest } \\
\text { measured } \\
\text { value }\end{array}$ & $\begin{array}{l}\text { highest } \\
\text { measured } \\
\text { value }\end{array}$ & $\begin{array}{l}\text { Range } \\
\text { Ratio }\end{array}$ & $\begin{array}{l}\text { estimated beta- } \\
\text { error smaller } \\
\text { than }\end{array}$ & $\begin{array}{l}\text { Federal } \\
\text { Register }\end{array}$ & Qualab & $\begin{array}{l}\text { Clinical } \\
\text { estimate }\end{array}$ \\
\hline \multirow[t]{2}{*}{ Albumin } & Alb & 47 & $g / L$ & 16 & 47.44 & 0.81 & 1.71 & 3.65 & 25 & 48 & 1.92 & $<10 \%$ & $\pm 10 \%$ & $\pm 15 \%$ & \\
\hline & Alb & 30.9 & $\mathrm{~g} / \mathrm{L}$ & 18 & 31.71 & 0.71 & 2.28 & & & & & & & & \\
\hline \multirow{2}{*}{$\begin{array}{c}\text { Alcaline } \\
\text { Phosphatase }\end{array}$} & AP & 71.9 & $U / L$ & 18 & 70.56 & 1.04 & 1.47 & 67.80 & 36 & 416 & 11.56 & $<5 \%$ & $\pm 30 \%$ & $\pm 21 \%$ & \\
\hline & AP & 210 & $U / L$ & 13 & 207.53 & 3.39 & 1.63 & & & & & & & & \\
\hline \multirow{2}{*}{$\begin{array}{c}\text { Alanin } \\
\text { aminotransferase }\end{array}$} & ALTL & 45.5 & $U / L$ & 17 & 45.65 & 0.49 & 1.07 & 36.10 & 7 & 354 & 50.57 & $<5 \%$ & $\pm 20 \%$ & $\pm 21 \%$ & \\
\hline & ALTL & 126 & $U / L$ & 19 & 126.47 & 1.58 & 1.25 & & & & & & & & \\
\hline \multirow[t]{3}{*}{ Amikacin } & Amik & 7.83 & umol/L & 9 & 8.822 & 1.057 & 11.98 & 0.28 & 0 & 2.8 & UD! & $<10 \%$ & & & $10 \%$ \\
\hline & Amik & 23.1 & umol/L & 9 & 23.828 & 1.341 & 5.63 & & & & & & & & \\
\hline & Amik & 46.3 & umol/L & 11 & 48.225 & 2.994 & 6.2 & & & & & & & & \\
\hline \multirow[t]{2}{*}{ Pancreatic Amylase } & Amy-P & 40 & $U / L$ & 18 & 39.83 & 0.71 & 1.78 & 19.88 & 2 & 157 & 78.50 & $<5 \%$ & & $\pm 25 \%$ & \\
\hline & Amy-P & 107 & $U / L$ & 19 & 107.11 & 1.05 & 0.98 & & & & & & & & \\
\hline \multirow[t]{2}{*}{ Amylase } & Amyl & 79.5 & $U / L$ & 16 & 79.31 & 0.79 & 1 & 29.25 & 13 & 182 & 14.00 & $<5 \%$ & $\pm 30 \%$ & $\pm 30 \%$ & \\
\hline & Amyl & 198 & $\mathrm{U} / \mathrm{L}$ & 12 & 195.56 & 1.42 & 0.73 & & & & & & & & \\
\hline \multirow{3}{*}{$\begin{array}{c}\text { Aspartate } \\
\text { aminotransferase }\end{array}$} & ASTL & 47.3 & $U / L$ & 17 & 46.59 & 1.18 & 2.53 & 25.40 & 10 & 244 & 24.40 & $<5 \%$ & $\pm 20 \%$ & $\pm 21 \%$ & \\
\hline & ASTL & 152 & $U / L$ & 19 & 15.063 & 3.18 & 2.11 & & & & & & & & \\
\hline & Bili-D & 28.1 & umol/L & 19 & 28.326 & 1.125 & 3.97 & 22.20 & 1.1 & 220.9 & 200.82 & & & & $20 \%$ \\
\hline \multirow[t]{2}{*}{ Total Bilirubin } & Bili-T & 16.5 & umol/L & 17 & 16.888 & 0.376 & 2.23 & 6.84 & 2.8 & 213.9 & 76.39 & $<5 \%$ & $\begin{array}{c} \pm 6.84 \text { umol/ } \\
\mathrm{L} \text { or } \pm 20 \%\end{array}$ & $\pm 20 \%$ & \\
\hline & Bili-T & 76.3 & umol/L & 19 & 75.421 & 5.257 & 6.97 & & & & & & & & \\
\hline \multirow[t]{2}{*}{ Calcium } & $\mathrm{Ca}$ & 2.13 & $\mathrm{mmol} / \mathrm{L}$ & 18 & 2.1233 & 0.0406 & 1.91 & 0.25 & 1.87 & 2.71 & 1.45 & $<10 \%$ & $\pm 0.25 \mathrm{umol} / \mathrm{L}$ & $\pm 12 \%$ & \\
\hline & $\mathrm{Ca}$ & 3.41 & $\mathrm{mmol} / \mathrm{L}$ & 21 & 3.3681 & 0.0515 & 1.53 & & & & & & & & \\
\hline \multirow[t]{3}{*}{ Carbamazepine } & Carb & 13.6 & umol/L & 9 & 11.6 & 1.773 & 15.28 & 0.13 & 0 & 1 & UD & $<5 \%$ & $\pm 25 \%$ & & \\
\hline & Carb & 37.9 & umol/L & 10 & 330.46 & 3.45 & 10.31 & & & & & & & & \\
\hline & Carb & 60.9 & umol/L & 11 & 54.955 & 4.377 & 7.96 & & & & & & & & \\
\hline \multirow[t]{2}{*}{ Cholinesterase } & $\mathrm{CHE}$ & 5400 & $U / L$ & 16 & 5232.13 & 98.07 & 1.87 & 1216.80 & 2877 & 9291 & 3.23 & $<5 \%$ & & & $20 \%$ \\
\hline & CHE & 1340 & $\mathrm{U} / \mathrm{L}$ & 18 & 1313.78 & 26.47 & 2.01 & & & & & & & & \\
\hline Cholesterol & Chol & 2.65 & $\mathrm{mmol} / \mathrm{L}$ & 17 & 2.718 & 0.039 & 1.43 & 0.51 & 2.3 & 7.8 & 3.39 & $<10 \%$ & $\pm 10 \%$ & $\pm 10 \%$ & \\
\hline Cholesterol & Chol & 5.27 & $\mathrm{mmol} / \mathrm{L}$ & 18 & 5.117 & 0.051 & 1 & & & & & & & & \\
\hline \multirow[t]{2}{*}{ Creatinin Kinase } & CK & 152 & $U / L$ & 18 & 148.78 & 1.7 & 1.14 & 69.60 & 12 & 452 & 37.67 & $<5 \%$ & $\pm 30 \%$ & $\pm 30 \%$ & \\
\hline & CK & 499 & $U / L$ & 18 & 494.56 & 6.29 & 1.27 & & & & & & & & \\
\hline$C K$, iso-enzyme $M B$ & CKMB & 5.13 & $\mathrm{ng} / \mathrm{mL}$ & 9 & 5.43 & 0.063 & 1.16 & 1.45 & 0.9 & 21.2 & 23.56 & ? & $\pm 3 \mathrm{SD}$ & & \\
\hline
\end{tabular}


Table 1 All test analyzed, their control values and further data used for estimation of the beta error. (Continued)

\begin{tabular}{|c|c|c|c|c|c|c|c|c|c|c|c|c|c|c|}
\hline & CKMB & 56.7 & $\mathrm{ng} / \mathrm{mL}$ & 7 & 55.62 & 0.903 & 1.62 & & & & & & & \\
\hline \multirow[t]{2}{*}{ Bicarbonate } & $\mathrm{CO} 2$ & 18.1 & $\mathrm{mmol} / \mathrm{L}$ & 17 & 18.575 & 0.331 & 1.78 & 2.08 & 10.3 & 31.3 & 3.04 & $<10 \%$ & & $10 \%$ \\
\hline & $\mathrm{CO} 2$ & 31.6 & $\mathrm{mmol} / \mathrm{L}$ & 17 & 31.292 & 0.63 & 2.01 & & & & & & & \\
\hline \multirow[t]{2}{*}{ Cortisol } & Cort & 300 & $\mathrm{nmol} / \mathrm{L}$ & 16 & 312.6 & 10.22 & 3.27 & 190.83 & 110.6 & 1416 & 12.80 & $<5 \%$ & $\pm 25 \%$ & $\pm 20 \%$ \\
\hline & Cort & 723 & $\mathrm{nmol} / \mathrm{L}$ & 13 & 733.3 & 12.22 & 1.67 & & & & & & & \\
\hline \multirow[t]{2}{*}{ Creatinine } & Crea & 89.1 & umol/L & 18 & 91.06 & 3.28 & 3.6 & 37.13 & 40 & 455 & 11.38 & $<5 \%$ & \pm 26.5 & ol/L or $\pm 15 \%$ \\
\hline & Crea & 346 & umol/L & 18 & 345.61 & 6.98 & 2.02 & & & & & & & \\
\hline \multirow[t]{2}{*}{ C-reactive Protein } & CRP & 9.7 & $\mathrm{mg} / \mathrm{L}$ & 15 & 9.653 & 0.223 & 2.31 & 16.26 & 0.3 & 216.5 & 721.67 & $<5 \%$ & & $\pm 21 \%$ \\
\hline & CRP & 53.2 & $\mathrm{mg} / \mathrm{L}$ & 16 & 52.706 & 2.088 & 3.96 & & & & & & & \\
\hline \multirow[t]{2}{*}{ Chloride } & $\mathrm{Cl}$ & 84.8 & $\mathrm{mmol} / \mathrm{L}$ & 28 & 83.709 & 2.623 & 3.13 & 5.15 & 87.9 & 118.1 & 1.34 & $>30 \%$ & $\pm 5 \%$ & $\pm 9 \%$ \\
\hline & $\mathrm{Cl}$ & 118 & $\mathrm{mmol} / \mathrm{L}$ & 28 & 114.967 & 2.066 & 1.8 & & & & & & & \\
\hline \multirow[t]{2}{*}{ Digoxin } & Digo & $\begin{array}{l}1.382 / \\
1.48\end{array}$ & $\mathrm{nmol} / \mathrm{L}$ & 10 & & 0.048 & 1.4 & 0.41 & 0.192 & 3.09 & 16.09 & $<5 \%$ & $\pm 25 \%$ & $\begin{array}{c} \pm 24 \%(<1 \mathrm{nmol} / \\
\mathrm{L}: \pm 0.24 \%)\end{array}$ \\
\hline & Digo & 3.699 & $\mathrm{nmol} / \mathrm{L}$ & 7 & 3.66 & 0.084 & 2.30 & & & & & & & \\
\hline \multirow[t]{2}{*}{ Aethyl-ethanol } & $\mathrm{ETOH}$ & 11.3 & $\mathrm{mmol} / \mathrm{L}$ & 15 & 11.253 & 0.767 & 6.82 & 0.16 & -0.4 & 1.7 & -4.25 & $<5 \%$ & $\pm 25 \%$ & \\
\hline & ETOH & 33.2 & $\mathrm{mmol} / \mathrm{L}$ & 14 & 33.35 & 2.69 & 8.07 & & & & & & & \\
\hline \multirow[t]{3}{*}{ Ferritin } & Ferri & 12.5 & ug/L & 10 & 13.95 & 0.333 & 2.39 & 216.84 & 8.7 & 1726 & 198.39 & $<5 \%$ & & $\pm 25 \%$ \\
\hline & Ferri & 416 & $\mathrm{ug} / \mathrm{L}$ & 10 & 412.4 & 13.21 & 3.2 & & & & & & & \\
\hline & Ferri & 1330 & $\mathrm{ug} / \mathrm{L}$ & 12 & 1283 & 61.71 & 4.81 & & & & & & & \\
\hline \multirow[t]{3}{*}{ Folic acid } & Fol & $\begin{array}{c}6.765 / \\
7.08 \\
\end{array}$ & $\mathrm{nmol} / \mathrm{L}$ & 11 & & 0.639 & 9.35 & 5.48 & 9.44 & 45.4 & 4.81 & $<5 \%$ & & $\pm 20 \%$ \\
\hline & Fol & 16.91 & $\mathrm{nmol} / \mathrm{L}$ & 11 & 17.381 & 0.604 & 3.48 & & & & & & & \\
\hline & Fol & 34.731 & $\mathrm{nmol} / \mathrm{L}$ & 12 & 35.185 & 2.26 & 6.42 & & & & & & & \\
\hline \multirow{2}{*}{$\begin{array}{l}\text { Free Tri-iodo } \\
\text { thyronine }\end{array}$} & FT3 & $6.1 / 6.33$ & $\mathrm{pmol} / \mathrm{L}$ & 17 & & 0.157 & 2.52 & 0.84 & 1.63 & 6.78 & 4.16 & $<5 \%$ & & $20 \%$ \\
\hline & FT3 & $\begin{array}{l}25.6 / \\
26.0\end{array}$ & $\mathrm{pmol} / \mathrm{L}$ & 15 & & 0.6588 & 2.658 & & & & & & & \\
\hline \multirow[t]{2}{*}{ Free Thyroxine } & FT4 & 14.3 & $\mathrm{pmol} / \mathrm{L}$ & 16 & 15.82 & 0.54 & 3.41 & 3.84 & 11.27 & 27.13 & 2.41 & $<5 \%$ & $\pm 3 \mathrm{SD}$ & $\pm 20 \%$ \\
\hline & FT4 & 51.6 & $\mathrm{pmol} / \mathrm{L}$ & 16 & 55.69 & 2.42 & 4.35 & & & & & & & \\
\hline \multirow[t]{3}{*}{ Gentamycine } & Gent & 3.68 & umol/L & 9 & 3.189 & 0.586 & 18.38 & 1.33 & 0 & 10.6 & UD & $<5 \%$ & $\pm 25 \%$ & \\
\hline & Gent & 9.38 & umol/L & 10 & 9.02 & 0.944 & 10.47 & & & & & & & \\
\hline & Gent & 15.8 & umol/L & 11 & 15.891 & 0.879 & 5.53 & & & & & & & \\
\hline \multirow{2}{*}{$\begin{array}{c}\text {-glutamyl } \\
\text { transpeptidase }\end{array}$} & GGT & 46.4 & $\mathrm{U} / \mathrm{L}$ & 17 & 45.65 & 0.61 & 1.34 & 195.30 & 9 & 1851 & 205.67 & $<5 \%$ & & $\pm 21 \%$ \\
\hline & GGT & 206 & $\mathrm{U} / \mathrm{L}$ & 18 & 205.89 & 2.85 & 1.38 & & & & & & & \\
\hline
\end{tabular}


Table 1 All test analyzed, their control values and further data used for estimation of the beta error. (Continued)

\begin{tabular}{|c|c|c|c|c|c|c|c|c|c|c|c|c|c|c|c|}
\hline Glucose & Gluc & 5.09 & $\mathrm{mmol} / \mathrm{L}$ & 19 & 5.07 & 0.092 & 1.81 & 0.86 & 4.6 & 12.6 & 2.74 & $<10 \%$ & $\begin{array}{c} \pm 0.333 \\
\mathrm{mmol} / \mathrm{L} \text { or } \pm \\
10 \%\end{array}$ & $\pm 10 \%$ & \\
\hline & Gluc & 13.2 & $\mathrm{mmol} / \mathrm{L}$ & 18 & 13.232 & 0.273 & 2.06 & & & & & & & & \\
\hline \multirow[t]{2}{*}{ Anti-Hepatitis A lgG } & HAV & $\begin{array}{l}18.5 / \\
18.7 / \\
20.5\end{array}$ & $\mathrm{IU} / \mathrm{L}$ & 13 & & 0.505 & 2.57 & 6.30 & 3 & 60 & 20.00 & $<5 \%$ & & & $20 \%$ \\
\hline & HAV & $\begin{array}{l}32.1 / \\
33.5 / \\
37.1\end{array}$ & IU/L & 15 & & 0.778 & 2.39 & & & & & & & & \\
\hline \multirow{2}{*}{$\begin{array}{l}\text { Human chorionic } \\
\text { gonadotropin, } \\
\text { Subunit }\end{array}$} & HCG-beta & 9.52 & $\mathrm{mlU} / \mathrm{mL}$ & 17 & 9.278 & 0.21 & 2.26 & 2.90 & 0.1 & 23.1 & 231.00 & $<5 \%$ & $\pm 3 \mathrm{SD}$ & $\pm 25 \%$ & \\
\hline & HCG-beta & 38.1 & $\mathrm{mlU} / \mathrm{mL}$ & 16 & 36.654 & 1.018 & 2.78 & & & & & & & & \\
\hline \multirow{2}{*}{$\begin{array}{l}\text { High-density } \\
\text { lipoprotein }\end{array}$} & $\mathrm{HDL}$ & 1.2 & $\mathrm{mmol} / \mathrm{L}$ & 17 & 1.15 & 0.0278 & 2.42 & 0.41 & 0.12 & 2.63 & 21.92 & $<5 \%$ & & $\pm 30 \%$ & \\
\hline & $\mathrm{HDL}$ & 0.74 & $\mathrm{mmol} / \mathrm{L}$ & 18 & 0.6461 & 0.0154 & 2.38 & & & & & & & & \\
\hline \multirow[t]{2}{*}{ Iron } & Iron & 20 & umol/L & 18 & 20.131 & 0.304 & 1.51 & 2.89 & 1.9 & 27 & 14.21 & $<5 \%$ & $\pm 20 \%$ & $\pm 20 \%$ & \\
\hline & Iron & 29.5 & umol/L & 19 & 29.684 & 0.332 & 1.12 & & & & & & & & \\
\hline \multirow[t]{2}{*}{ Potassium } & $K$ & 3.41 & $\mathrm{mmol} / \mathrm{L}$ & 27 & 3.3661 & 0.08 & 2.38 & 0.50 & 2.3 & 5.11 & 2.22 & $<10 \%$ & $\pm 0.5 \mathrm{mmol} / \mathrm{L}$ & $\pm 9 \%$ & \\
\hline & K & 6.26 & $\mathrm{mmol} / \mathrm{L}$ & 28 & 6.1757 & 0.0916 & 1.48 & & & & & & & & \\
\hline \multirow{2}{*}{$\begin{array}{c}\text { Lactate } \\
\text { Dehydrogenase }\end{array}$} & LDH & 318 & $U / L$ & 16 & 321.38 & 3.74 & 1.16 & 143.10 & 232 & 1199 & 5.17 & $<5 \%$ & $\pm 20 \%$ & $\pm 21 \%$ & \\
\hline & $\mathrm{LDH}$ & 497 & $U / L$ & 17 & 501.82 & 4.52 & 0.9 & & & & & & & & \\
\hline \multirow{2}{*}{$\begin{array}{l}\text { Low-density } \\
\text { lipoprotein }\end{array}$} & LDL & 2.87 & $\mathrm{mmol} / \mathrm{L}$ & 16 & 2.7144 & 0.0669 & 2.46 & 1.03 & 0.89 & 5.97 & 6.71 & $<5 \%$ & & & $30 \%$ \\
\hline & LDL & 5.17 & $\mathrm{mmol} / \mathrm{L}$ & 18 & 4.7817 & 0.0932 & 1.95 & & & & & & & & \\
\hline \multirow[t]{2}{*}{ Lipase } & Lipe & 55.4 & $U / L$ & 18 & 54.28 & 0.67 & 1.23 & 97.68 & 6 & 808 & 134.67 & $<5 \%$ & & $\pm 24 \%$ & \\
\hline & Lipe & 89.9 & $U / L$ & 18 & 88.33 & 1.88 & 2.13 & & & & & & & & \\
\hline \multirow[t]{2}{*}{ Magnesium } & $\mathrm{Mg}$ & 0.892 & $\mathrm{mmol} / \mathrm{L}$ & 17 & 0.868 & 0.0268 & 3.09 & 0.26 & 0.51 & 1.56 & 3.06 & $<5 \%$ & $\pm 25 \%$ & $\pm 20 \%$ & \\
\hline & $\mathrm{Mg}$ & 1.68 & $\mathrm{mmol} / \mathrm{L}$ & 17 & 1.7065 & 0.0611 & 3.58 & & & & & & & & \\
\hline \multirow[t]{2}{*}{ Myoglobin } & Myo & 85.2 & $\mathrm{ng} / \mathrm{mL}$ & 11 & 80.107 & 2.025 & 2.53 & 28.68 & 21 & 170.2 & 8.10 & $<5 \%$ & & $\pm 30 \%$ & \\
\hline & Myo & 1080 & $\mathrm{ng} / \mathrm{mL}$ & 11 & 1003.3 & 43.704 & 4.36 & & & & & & & & \\
\hline \multirow[t]{2}{*}{ Sodium } & $\mathrm{Na}$ & 121 & $\mathrm{mmol} / \mathrm{L}$ & 27 & 119.79 & 2.92 & 2.44 & 12.69 & 129 & 153 & 1.19 & & $\pm 4 \mathrm{mmol} / \mathrm{L}$ & $\pm 9 \%$ & \\
\hline & $\mathrm{Na}$ & 145 & $\mathrm{mmol} / \mathrm{L}$ & 28 & 142.69 & 2.26 & 1.58 & & & & & & & & \\
\hline \multirow[t]{3}{*}{ Pheno-barbital } & Phno & 39.9 & umol/L & 10 & 39.9 & 1.91 & 4.79 & 0.80 & 0 & 8 & UD & $<5 \%$ & $\pm 20 \%$ & & \\
\hline & Phno & 105 & umol/L & 11 & 97.55 & 2.46 & 2.52 & & & & & & & & \\
\hline & Phno & 215 & umol/L & 10 & 198.2 & 5.2 & 2.62 & & & & & & & & \\
\hline Phosphate & Phos & 1.29 & $\mathrm{mmol} / \mathrm{L}$ & 17 & 1.3047 & 0.0194 & 1.49 & 0.20 & 0.62 & 2.06 & 3.32 & $<5 \%$ & & $\pm 15 \%$ & \\
\hline
\end{tabular}


Table 1 All test analyzed, their control values and further data used for estimation of the beta error. (Continued)

\begin{tabular}{|c|c|c|c|c|c|c|c|c|c|c|c|c|c|c|c|}
\hline & Phos & 2.01 & $\mathrm{mmol} / \mathrm{L}$ & 18 & 2.0472 & 0.0321 & 1.57 & & & & & & & & \\
\hline \multirow{2}{*}{$\begin{array}{l}\mathrm{N} \text {-terminal Brain } \\
\text { natriuretic peptide }\end{array}$} & Pro-BNP & 131 & $\mathrm{pg} / \mathrm{mL}$ & 12 & 134 & 5.85 & 4.37 & 1837.05 & 5 & 24489 & 4897.80 & $<5 \%$ & & $\pm 15 \%$ & \\
\hline & Pro-BNP & 4360 & $\mathrm{pg} / \mathrm{mL}$ & 11 & 4944 & 135.5 & 2.74 & & & & & & & & \\
\hline \multirow{3}{*}{$\begin{array}{l}\text { Parathyroid- } \\
\text { hormone }\end{array}$} & PTH & 5.7982 & $\mathrm{pmol} / \mathrm{L}$ & 7 & 5.47 & 0.165 & 3.01 & 5.13 & 2.12 & 40.61 & 19.16 & $<5 \%$ & & $\pm 24 \%$ & \\
\hline & PTH & 20.246 & $\mathrm{pmol} / \mathrm{L}$ & 5 & 19.94 & 0.278 & 1.4 & & & & & & & & \\
\hline & PTH & 86.39 & $\mathrm{pmol} / \mathrm{L}$ & 6 & 87.06 & 1.23 & 1.42 & & & & & & & & \\
\hline \multirow[t]{2}{*}{ Anti-Rubella lgG } & RubG & $\begin{array}{l}3.57 / \\
3.96\end{array}$ & $\mathrm{IU} / \mathrm{mL}$ & 13 & & 0.186 & 4.99 & 50.02 & 0.17 & 500 & 2941.18 & & (1) & & \\
\hline & RubG & 69.3 & $\mathrm{IU} / \mathrm{mL}$ & 12 & 70.85 & 4.68 & 6.61 & & & & & & & & \\
\hline \multirow[t]{2}{*}{ Anti-Rubella IgM } & RubM & 0.23 & $\mathrm{COI}$ & 13 & 0.224 & 0.008 & 3.57 & & & & UD & & (1) & & \\
\hline & RubM & 2 & $\mathrm{COI}$ & 13 & 1.816 & 0.128 & 7.05 & & & & & & & & \\
\hline \multirow[t]{3}{*}{ Salicylate } & Sali & 0.29 & $\mathrm{mmol} / \mathrm{L}$ & 9 & 0.2667 & 0.0324 & 12.15 & -0.02 & -0.22 & 0.05 & -0.23 & $<5 \%$ & & & $20 \%$ \\
\hline & Sali & 1.14 & $\mathrm{mmol} / \mathrm{L}$ & 10 & 1.1335 & 0.0362 & 3.19 & & & & & & & & \\
\hline & Sali & 3.12 & $\mathrm{mmol} / \mathrm{L}$ & 11 & 3.3218 & 0.0795 & 2.39 & & & & & & & & \\
\hline \multirow[t]{2}{*}{ Triiodo-thyronine } & $\mathrm{T} 3$ & 2.46 & $\mathrm{nmol} / \mathrm{L}$ & 16 & 2.34 & 0.179 & 7.66 & 0.30 & 0.541 & 2.47 & 4.57 & $<5 \%$ & $\pm 3 \mathrm{SD}$ & & $20 \%$ \\
\hline & T3 & 5.59 & $\mathrm{nmol} / \mathrm{L}$ & 16 & 5.48 & 0.383 & 7 & & & & & & & & \\
\hline \multirow[t]{3}{*}{ Theophyllin } & Theo & 30.1 & umol/L & 9 & 30.44 & 1.88 & 6.18 & 1.38 & 0 & 11 & UD & $<5 \%$ & $\pm 25 \%$ & & \\
\hline & Theo & 82.7 & umol/L & 10 & 83.1 & 2.51 & 3.02 & & & & & & & & \\
\hline & Theo & 171 & umol/L & 11 & 166.64 & 5.26 & 3.16 & & & & & & & & \\
\hline \multirow[t]{2}{*}{ Troponin T } & $\mathrm{TN}-\mathrm{T}$ & 0.071 & $u g / L$ & 13 & 0.073 & 0.003 & 4.11 & 0.31 & 0.01 & 2.54 & 254.00 & $<5 \%$ & & $\pm 24 \%$ & \\
\hline & $\mathrm{TN}-\mathrm{T}$ & 2.24 & $\mathrm{ug} / \mathrm{L}$ & 11 & 2.213 & 0.037 & 1.67 & & & & & & & & \\
\hline \multirow[t]{2}{*}{ High-sensitivity TNT } & TNT-hs & 0.0302 & $u g / L$ & 11 & 0.032 & 0.001 & 3.13 & 0.26 & 0.003 & 2.19 & 730.00 & $<5 \%$ & & $\pm 24 \%$ & \\
\hline & TNT-hs & 2.45 & $u g / L$ & 11 & 2.488 & 0.054 & 2.17 & & & & & & & & \\
\hline \multirow[t]{3}{*}{ Tobramycin } & Tobr & 1.79 & $\mathrm{ug} / \mathrm{mL}$ & 9 & 1.8 & 0.071 & 3.94 & 0.03 & 0 & 0.2 & UD & $<5 \%$ & $\pm 25 \%$ & & \\
\hline & Tobr & 4.01 & $\mathrm{ug} / \mathrm{mL}$ & 10 & 3.94 & 0.07 & 1.78 & & & & & & & & \\
\hline & Tobr & 8.17 & $\mathrm{ug} / \mathrm{mL}$ & 11 & 7.9 & 0.261 & 3.30 & & & & & & & & \\
\hline \multirow{2}{*}{$\begin{array}{l}\text { Anti-Toxo-plasma } \\
\text { lgG }\end{array}$} & ToxoG & 0.84 & $\mathrm{IU} / \mathrm{mL}$ & 13 & 0.899 & 0.051 & 5.67 & 77.25 & 0.13 & 617.9 & 4753.08 & $<5 \%$ & & & $20 \%$ \\
\hline & ToxoG & 48.1 & $\mathrm{IU} / \mathrm{mL}$ & 13 & 50.549 & 2.93 & 5.80 & & & & & & & & \\
\hline \multirow{2}{*}{$\begin{array}{c}\text { Anti-Toxo-plasma } \\
\text { IgM }\end{array}$} & ToxoM & 0.18 & $\mathrm{COI}$ & 13 & 0.14 & 0.015 & 10.71 & & -1 & -1 & 1.00 & & & & \\
\hline & ToxoM & 1.78 & $\mathrm{COI}$ & 13 & 1.86 & 0.057 & 3.06 & & & & & & & & \\
\hline \multirow[t]{3}{*}{ Total Protein } & $\mathrm{TP}$ & 64.6 & $\mathrm{~g} / \mathrm{L}$ & 14 & 65.786 & 1.122 & 1.71 & 7.00 & 50 & 90 & 1.80 & $<10 \%$ & $\pm 10 \%$ & $\pm 15 \%$ & \\
\hline & $\mathrm{TP}$ & 102 & $g / L$ & 15 & 105.23 & 1.05 & 1.00 & & & & & & & & \\
\hline & $\mathrm{TP}$ & 66.8 & $\mathrm{~g} / \mathrm{L}$ & 17 & 66.88 & 0.86 & 1.29 & & & & & & & & \\
\hline
\end{tabular}


Table 1 All test analyzed, their control values and further data used for estimation of the beta error. (Continued)

\begin{tabular}{|c|c|c|c|c|c|c|c|c|c|c|c|c|c|c|c|}
\hline & TP & 50.1 & $\mathrm{~g} / \mathrm{L}$ & 19 & 50.11 & 0.74 & 1.48 & & & & & & & & \\
\hline \multirow[t]{2}{*}{ Triglycerides } & Trigl & 1.22 & $\mathrm{mmol} / \mathrm{L}$ & 17 & 1.2371 & 0.0126 & 1.02 & 0.74 & 0.67 & 5.21 & 7.78 & $<5 \%$ & $\pm 25 \%$ & $\pm 20 \%$ & \\
\hline & Trigl & 2.37 & $\mathrm{mmol} / \mathrm{L}$ & 18 & 2.3711 & 0.0345 & 1.46 & & & & & & & & \\
\hline \multirow[t]{3}{*}{ Transferrin } & Trfe & 33 & umol/L & 13 & 33.154 & 0.689 & 2.08 & 6.30 & 16 & 47 & 2.94 & $<5 \%$ & & & $20 \%$ \\
\hline & Trfe & 48.9 & umol/L & 15 & 48.23 & 0.68 & 1.41 & & & & & & & & \\
\hline & Trfe & 25.1 & umol/L & 17 & 25.41 & 0.51 & 2.01 & & & & & & & & \\
\hline \multirow{2}{*}{$\begin{array}{l}\text { Thyroid-stimulating } \\
\text { hormone }\end{array}$} & TSH & 1.65 & $\mathrm{ulU} / \mathrm{mL}$ & 16 & 1.57 & 0.019 & 1.21 & 0.62 & 0.05 & 6.14 & 122.80 & $<5 \%$ & $\pm 3 S D$ & $\pm 20 \%$ & \\
\hline & TSH & 9.09 & $\mathrm{ulU} / \mathrm{mL}$ & 15 & 8.57 & 0.114 & 1.33 & & & & & & & & \\
\hline \multirow[t]{2}{*}{ Uric Acid } & UA & 275 & umol/L & 17 & 276.12 & 2.71 & 0.98 & 75.00 & 93 & 907 & 9.75 & $<5 \%$ & $\pm 17 \%$ & $\pm 15 \%$ & \\
\hline & UA & 579 & umol/L & 18 & 575.11 & 10.53 & 1.83 & & & & & & & & \\
\hline \multirow[t]{2}{*}{ Urea } & Ureal & 6.84 & $\mathrm{mmol} / \mathrm{L}$ & 17 & 6.9 & 0.094 & 1.36 & 4.15 & 2 & 39.5 & 19.75 & $<5 \%$ & & $\pm 20 \%$ & \\
\hline & Ureal & 24.4 & $\mathrm{mmol} / \mathrm{L}$ & 18 & 23.967 & 0.387 & 1.61 & & & & & & & & \\
\hline \multirow[t]{3}{*}{ Valproate } & Valp & 238 & umol/L & 9 & 233.44 & 29.75 & 12.74 & 3.88 & 0 & 31 & UD & $<5 \%$ & $\pm 25 \%$ & & \\
\hline & Valp & 519 & umol/L & 10 & 549 & 47.71 & 8.69 & & & & & & & & \\
\hline & Valp & 811 & umol/L & 11 & 857.45 & 69.14 & 8.06 & & & & & & & & \\
\hline \multirow[t]{3}{*}{ Vanco-mycin } & Vanc & 4.22 & umol/L & 10 & 4.59 & 0.468 & 10.2 & 0.18 & 0 & 1.8 & UD & $<5 \%$ & & & $20 \%$ \\
\hline & Vanc & 13.5 & umol/L & 10 & 15.52 & 0.914 & 5.89 & & & & & & & & \\
\hline & Vanc & 19.6 & umol/L & 12 & 22.083 & 0.997 & 4.51 & & & & & & & & \\
\hline \multirow[t]{3}{*}{ Vitamin B12 } & VitB12 & $\begin{array}{c}177.858 / \\
194.8\end{array}$ & $\mathrm{pmol} / \mathrm{L}$ & 11 & & 9.546 & 5.24 & 123.35 & 109.5 & 1124 & 10.26 & $<5 \%$ & & $\pm 20 \%$ & \\
\hline & VitB12 & $\begin{array}{c}392.616 / \\
408.9\end{array}$ & $\mathrm{pmol} / \mathrm{L}$ & 11 & & 11.8 & 2.99 & & & & & & & & \\
\hline & VitB12 & 856.08 & $\mathrm{pmol} / \mathrm{L}$ & 12 & 859.636 & 20.04 & 2.33 & & & & & & & & \\
\hline \multirow[t]{3}{*}{ Vitamin D } & VitD & 55 & $\mathrm{nmol} / \mathrm{L}$ & 6 & 48.36 & 6.93 & 14.33 & 14.71 & 17.78 & 129.3 & 7.27 & $<5 \%$ & & $\pm 20 \%$ & \\
\hline & VitD & 83.75 & $\mathrm{nmol} / \mathrm{L}$ & 4 & 72.95 & 6.92 & 9.49 & & & & & & & & \\
\hline & VitD & 115.5 & $\mathrm{nmol} / \mathrm{L}$ & 6 & 106.5 & 10.31 & 9.68 & & & & & & & & \\
\hline
\end{tabular}

(1) Target value \pm 2 dilutions or immune or nonimmune or positive or negative, $U D=$ undetermined

All analyses were listed including their abbreviations used in the further tables. Their standard deviations (SD) and coefficient of variations (CV) of the controls (QC) are given. The target values of the QC material of different analytes, as well as the measurement units, the number of QC repetitions (n), the mean, SD and CV of the QC materials are displayed. The beta error was estimated [12] using the range ratio and the allowable biases as defined by the federal registry, the Qualab or the clinical estimate. The values used for the evaluations are displayed in bold. 
informed consent. Their samples were immediately anonymized after blood draw, but were decoded upon request of the patients.

\subsection{Statistics}

Analyse-it for Excel (Version 2.11, 2008) was used for the statistical analyses; the statistic procedure applied being the Deming fit. In contrast to linear regression analysis, the Deming procedure allows for a random error in both test and reference measurements [10]. Performed with weighed function, it accounts also for a non-constant random error over the measurement range $[11,12]$. A two sided $p$ value of $<0.05$ was considered as significant. Coefficients of variation $(\mathrm{CV})$ and standard deviations (SD) were calculated by the Cobas 6000 software from the quality control samples as mentioned in table 1 . These quality controls were run once a day.

\subsubsection{Determination of the alpha error}

The triplicates of each parameter of tubes 11 (comprising all different centrifugation conditions) per patient were compared with those of tube 22, to detect variations caused by the different gel separators. Second, test results from all centrifugation conditions within one tube were compared among each other. As singletons were compared, SD or CV had to be defined using the values of the quality control samples displayed in table 1. If the SD's were approximately constant over the measured range, the mean of SD's of those quality control samples were entered. In case CV was more constant than SD, a weighed Deming fit was applied using the means of CV's of those quality control samples.

\subsubsection{Determination of the beta error}

The null hypothesis of the Deming fit tests the identity of a test method to a reference method. The $\mathrm{p}$ value defines the probability (alpha error) that the two methods deliver identical results. However, it does not determine the probability to detect a deviation of the test method from the reference method when in fact the test method produces aberrant or biased results. The probability to miss an existent bias (beta error) depends on the measurement range, the allowable bias, the analytical measurement error and the distribution of the data [12]. First, we estimated the beta error based on the tables five and six of publication [12], using the measurement range of our data. As allowable bias the values were primarily taken from Federal registry [13], secondarily from the Swiss regulation of Qualab [14], and thirdly by an estimate of clinical requirement by one of the investigators (EIM) The data used are highlighted on table 1. Second, we calculated the deviation or bias of the test method to the reference method for the limits of reference values. The calculated bias was compared to an allowable bias of $5 \%, 10 \% 20 \%, 30 \%$ or $40 \%$ and the probability was determined that the calculated bias exceeds the allowable bias thus indicating a significant deviation of the test method from the reference method.

\section{Results}

As an illustrative example of the applied Deming method, the scatter plot, the residual plot and the correspondent numeric output of alanin-amino-transferase (ALAT) measurements are shown in Figure 1. The means of the triplicates of tube 11 are compared with those of tube 22. Figure 1A shows that the identity and the weighted Deming regression line lie closely to each other. Figure 1B illustrates that the deviation of the standardized residuals strongly increase in lower values, indicating that a weighted rather than unweighted procedure should be applied. On the lower part of Figure 1, the numerical results of the constant and proportional bias and their $\mathrm{p}$ values are displayed. The constant bias corresponding to the intercept in regression analysis should be 0.00 ideally, the proportional bias corresponding to the slope 1.00 . The $\mathrm{p}$ value of 0.57 for the constant bias and that of 0.87 for the proportional bias indicate that neither the slope nor the intercept differs significantly from their ideal values.

A compilation of the constant and proportional bias over all statistical tests including all parameters and all centrifugation conditions is displayed in additional file 1 , table $\mathrm{S} 1$ and an excerpt of them is illustrated in table 2. The leftmost column shows the parameter analyzed. For each parameter, seven statistical comparisons as displayed in the adjacent columns were made, resulting in 357 Deming tests (51 parameters $\times 7$ comparisons). One tube 22, condition 2 was excluded because several analytical parameters showed aberrations that exceeded 3 standardized residuals, and we concluded that this tube did not contain a sample of appropriate quality. Twenty-three analytical parameters could not be evaluated, as either, they were not quantitative tests or most patient samples did not contain measurable amounts and therefore a reliable quantitative comparison could not be performed. They are listed as footnotes in additional file 1, table S1.

Table 2 and additional file 1, table S1 list the statistical evaluations on all investigated parameters including the constant bias, the proportional bias and their $95 \%$ confidence intervals. The $95 \%$ confidence intervals included the ideal values (i.e. 0.00 in constant bias or 1.00 in proportional bias) for 688 of the 714 results (357 each constant and proportional bias), and not included in this interval were 26 results (18 constant, 8 proportional biases). These data correspond to $3.6 \%$ of the 714 results, $5.0 \%$ of constant and $2.2 \%$ of proportional biases, respectively. These percentages do not surpass the expected $5 \%$, as the confidence intervals include only $95 \%$ and not $100 \%$ of random variations. Moreover, 


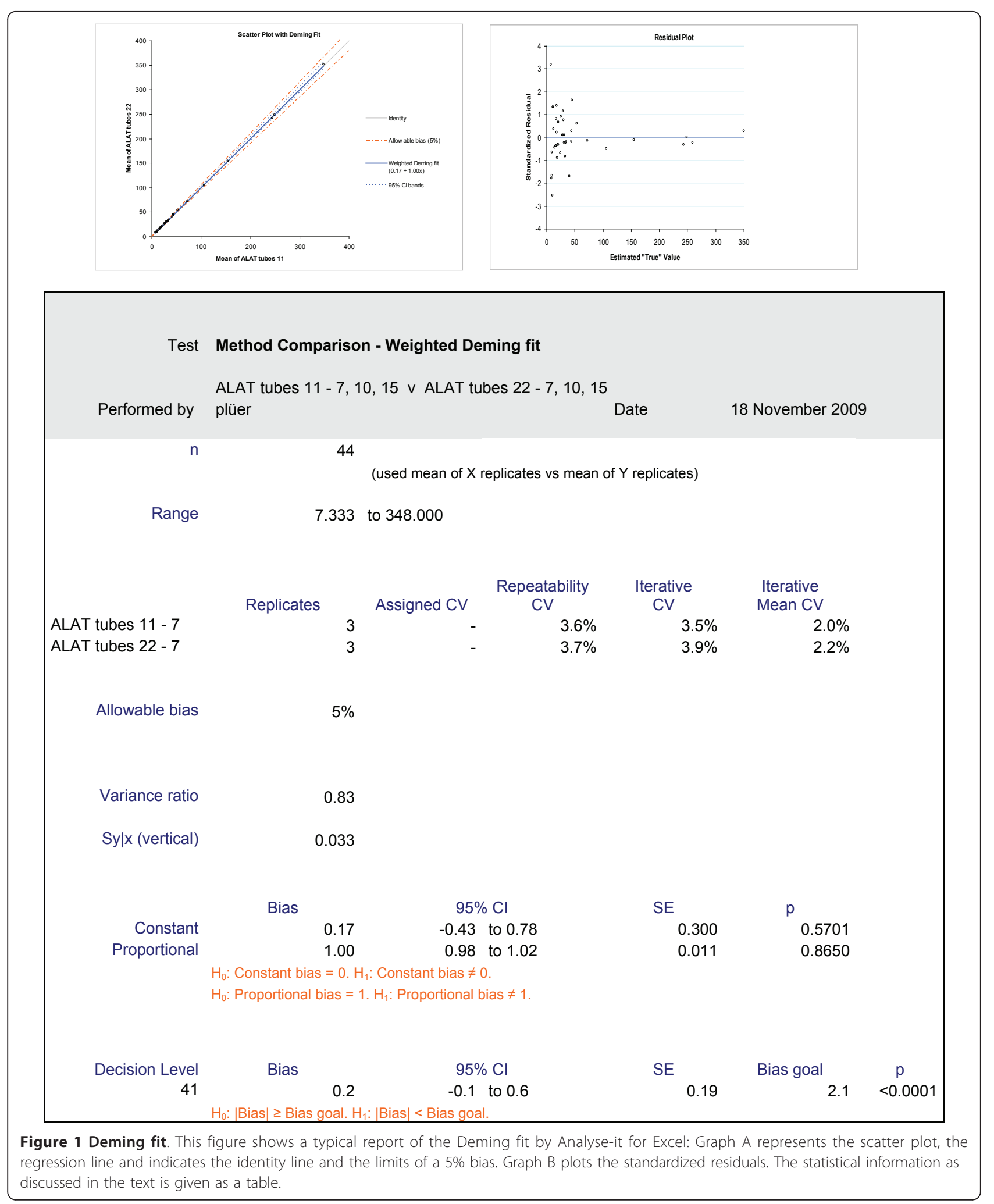


Table 2 An illustrative excerpt of all Deming fits containing the data of some clinical chemistry and immunology analytes.

\begin{tabular}{|c|c|c|c|c|c|c|c|c|c|c|c|c|c|c|}
\hline \multirow[t]{2}{*}{ Analysis } & \multicolumn{2}{|c|}{$11: 22$} & \multicolumn{2}{|c|}{$11-15: 10$} & \multicolumn{2}{|c|}{$11-15: 7$} & \multicolumn{2}{|c|}{$11-10: 7$} & \multicolumn{2}{|c|}{$22-15: 10$} & \multicolumn{2}{|c|}{$22-15: 7$} & \multicolumn{2}{|c|}{$22-10: 7$} \\
\hline & $\begin{array}{l}\text { Bias } \\
\text { Const. }\end{array}$ & Prop. & $\begin{array}{c}\text { Bias } \\
\text { Const. }\end{array}$ & Prop. & $\begin{array}{c}\text { Bias } \\
\text { Const. }\end{array}$ & Prop. & $\begin{array}{c}\text { Bias } \\
\text { Const. }\end{array}$ & Prop. & $\begin{array}{l}\text { Bias } \\
\text { Const. }\end{array}$ & Prop. & $\begin{array}{l}\text { Bias } \\
\text { Const. }\end{array}$ & Prop. & $\begin{array}{l}\text { Bias } \\
\text { Const. }\end{array}$ & Prop. \\
\hline & $95 \% \mathrm{Cl}$ & $95 \% \mathrm{Cl}$ & $95 \% \mathrm{Cl}$ & $95 \% \mathrm{Cl}$ & $95 \% \mathrm{Cl}$ & $95 \% \mathrm{Cl}$ & $95 \% \mathrm{Cl}$ & $95 \% \mathrm{Cl}$ & $95 \% \mathrm{Cl}$ & $95 \% \mathrm{Cl}$ & $95 \% \mathrm{Cl}$ & $95 \% \mathrm{Cl}$ & $95 \% \mathrm{Cl}$ & $95 \% \mathrm{Cl}$ \\
\hline Alb & -1.81 & 1.06 & -1.86 & 1.06 & -1.05 & 1.03 & 0.76 & 0.98 & -0.16 & 1.01 & 0.25 & 0.99 & 0.40 & 0.99 \\
\hline Alb & $\begin{array}{c}-4.33 \text { to } \\
0.71\end{array}$ & $\begin{array}{c}0.99 \text { to } \\
1.13\end{array}$ & $\begin{array}{c}-4.52 \text { to } \\
0.79\end{array}$ & $\begin{array}{c}0.98 \text { to } \\
1.13\end{array}$ & $\begin{array}{c}-2.55 \text { to } \\
0.45\end{array}$ & $\begin{array}{c}0.99 \text { to } \\
1.07\end{array}$ & $\begin{array}{c}-1.90 \text { to } \\
3.41\end{array}$ & $\begin{array}{c}0.90 \text { to } \\
1.05\end{array}$ & $\begin{array}{c}-2.54 \text { to } \\
2.23\end{array}$ & $\begin{array}{c}0.94 \text { to } \\
1.07\end{array}$ & $\begin{array}{c}-1.85 \text { to } \\
2.34\end{array}$ & $\begin{array}{c}0.94 \text { to } \\
1.05\end{array}$ & $\begin{array}{c}-1.83 \text { to } \\
2.63\end{array}$ & $\begin{array}{c}0.93 \text { to } \\
1.04\end{array}$ \\
\hline Bili-T & -0.08 & 1.01 & -0.15 & 1.03 & 0.10 & 1.00 & 0.24 & 0.96 & -0.04 & 1.01 & -0.11 & 1.03 & -0.06 & 1.02 \\
\hline$\overline{\text { Bili-T }}$ & $\begin{array}{c}-0.18 \text { to } \\
0.01\end{array}$ & $\begin{array}{c}0.99 \text { to } \\
1.02\end{array}$ & $\begin{array}{c}-0.44 \text { to } \\
0.15\end{array}$ & $\begin{array}{c}1.00 \text { to } \\
1.06\end{array}$ & $\begin{array}{c}-0.18 \text { to } \\
0.38\end{array}$ & $\begin{array}{l}0.96 \text { to } \\
1.03\end{array}$ & $\begin{array}{c}0.04 \text { to } \\
0.44\end{array}$ & $\begin{array}{c}0.94 \text { to } \\
0.99\end{array}$ & $\begin{array}{c}-0.39 \text { to } \\
0.31\end{array}$ & $\begin{array}{l}0.97 \text { to } \\
1.05\end{array}$ & $\begin{array}{c}-0.52 \text { to } \\
0.29\end{array}$ & $\begin{array}{c}0.99 \text { to } \\
1.07\end{array}$ & $\begin{array}{c}-0.45 \text { to } \\
0.32\end{array}$ & $\begin{array}{c}0.98 \text { to } \\
1.07\end{array}$ \\
\hline $\mathrm{Ca}$ & -0.05 & 1.03 & -0.17 & 1.08 & -0.18 & 1.08 & -0.01 & 1.00 & -0.09 & 1.04 & -0.05 & 1.02 & 0.02 & 0.99 \\
\hline $\mathrm{Ca}$ & $\begin{array}{c}-0.15 \text { to } \\
0.04\end{array}$ & $\begin{array}{c}0.99 \text { to } \\
1.07\end{array}$ & $\begin{array}{c}-0.35 \text { to } \\
0.02\end{array}$ & $\begin{array}{c}0.99 \text { to } \\
1.16\end{array}$ & $\begin{array}{c}-0.33 \text { to } \\
-0.02\end{array}$ & $\begin{array}{l}1.01 \text { to } \\
1.15\end{array}$ & $\begin{array}{c}-0.13 \text { to } \\
0.11\end{array}$ & $\begin{array}{l}0.95 \text { to } \\
1.05\end{array}$ & $\begin{array}{c}-0.24 \text { to } \\
0.05\end{array}$ & $\begin{array}{c}0.98 \text { to } \\
1.10\end{array}$ & $\begin{array}{c}-0.20 \text { to } \\
0.09\end{array}$ & $\begin{array}{c}0.96 \text { to } \\
1.09\end{array}$ & $\begin{array}{c}-0.12 \text { to } \\
0.16\end{array}$ & $\begin{array}{c}0.93 \text { to } \\
1.05\end{array}$ \\
\hline CK & 0.15 & 1.00 & -0.40 & 1.01 & -1.63 & 1.02 & -1.20 & 1.01 & -0.98 & 1.03 & -0.66 & 1.02 & 0.31 & 0.99 \\
\hline CK & $\begin{array}{c}-0.19 \text { to } \\
0.49\end{array}$ & $\begin{array}{c}0.99 \text { to } \\
1.01 \\
\end{array}$ & $\begin{array}{c}-1.43 \text { to } \\
0.62\end{array}$ & $\begin{array}{l}1.00 \text { to } \\
1.03\end{array}$ & $\begin{array}{c}-2.54 \text { to } \\
-0.71\end{array}$ & $\begin{array}{l}1.00 \text { to } \\
1.03\end{array}$ & $\begin{array}{c}-2.89 \text { to } \\
0.50\end{array}$ & $\begin{array}{c}0.98 \text { to } \\
1.03 \\
\end{array}$ & $\begin{array}{c}-2.80 \text { to } \\
0.85 \\
\end{array}$ & $\begin{array}{c}1.00 \text { to } \\
1.06\end{array}$ & $\begin{array}{c}-1.48 \text { to } \\
0.17 \\
\end{array}$ & $\begin{array}{c}1.00 \text { to } \\
1.03\end{array}$ & $\begin{array}{c}-2.11 \text { to } \\
2.74 \\
\end{array}$ & $\begin{array}{c}0.95 \text { to } \\
1.03\end{array}$ \\
\hline CKMB & 0.23 & 0.94 & -0.62 & 1.15 & -0.15 & 1.01 & 0.42 & 0.87 & -0.11 & 1.03 & -0.10 & 1.01 & 0.01 & 0.98 \\
\hline CKMB & $\begin{array}{c}-0.11 \text { to } \\
0.58\end{array}$ & $\begin{array}{c}0.85 \text { to } \\
1.02\end{array}$ & $\begin{array}{c}-2.29 \text { to } \\
1.05\end{array}$ & $\begin{array}{c}0.74 \text { to } \\
1.56\end{array}$ & $\begin{array}{c}-0.40 \text { to } \\
0.09\end{array}$ & $\begin{array}{c}0.96 \text { to } \\
1.06\end{array}$ & $\begin{array}{c}-1.06 \text { to } \\
1.89 \\
\end{array}$ & $\begin{array}{c}0.50 \text { to } \\
1.24\end{array}$ & $\begin{array}{c}-0.55 \text { to } \\
0.33\end{array}$ & $\begin{array}{c}0.91 \text { to } \\
1.14\end{array}$ & $\begin{array}{c}-0.64 \text { to } \\
0.44\end{array}$ & $\begin{array}{c}0.87 \text { to } \\
1.15\end{array}$ & $\begin{array}{c}-0.26 \text { to } \\
0.29\end{array}$ & $\begin{array}{c}0.92 \text { to } \\
1.05\end{array}$ \\
\hline FT3 & 0.08 & 0.98 & -0.18 & 1.05 & -0.20 & 1.06 & -0.01 & 1.00 & -0.08 & 1.05 & -0.24 & 1.07 & -0.06 & 1.02 \\
\hline FT3 & $\begin{array}{c}-0.10 \text { to } \\
0.26\end{array}$ & $\begin{array}{c}0.93 \text { to } \\
1.03\end{array}$ & $\begin{array}{c}-0.36 \text { to } \\
-0.00\end{array}$ & $\begin{array}{c}1.00 \text { to } \\
1.11\end{array}$ & $\begin{array}{c}-0.42 \text { to } \\
0.03\end{array}$ & $\begin{array}{c}0.99 \text { to } \\
1.12\end{array}$ & $\begin{array}{c}-0.27 \text { to } \\
0.24\end{array}$ & $\begin{array}{c}0.93 \text { to } \\
1.08\end{array}$ & $\begin{array}{c}-0.52 \text { to } \\
0.17 \\
\end{array}$ & $\begin{array}{c}0.96 \text { to } \\
1.14\end{array}$ & $\begin{array}{c}-0.67 \text { to } \\
0.20 \\
\end{array}$ & $\begin{array}{c}0.95 \text { to } \\
1.18 \\
\end{array}$ & $\begin{array}{c}-0.28 \text { to } \\
0.17 \\
\end{array}$ & $\begin{array}{c}0.96 \text { to } \\
1.08\end{array}$ \\
\hline FT4 & -0.22 & 1.02 & -0.69 & 1.05 & -0.76 & 1.05 & -0.05 & 1.00 & -0.56 & 1.04 & 0.73 & 1.04 & -0.17 & 1.01 \\
\hline FT4 & $\begin{array}{c}-0.63 \text { to } \\
0.19\end{array}$ & $\begin{array}{c}0.99 \text { to } \\
1.04\end{array}$ & $\begin{array}{c}-1.88 \text { to } \\
0.51\end{array}$ & $\begin{array}{c}0.97 \text { to } \\
1.12\end{array}$ & $\begin{array}{c}-2.40 \text { to } \\
0.89\end{array}$ & $\begin{array}{c}0.95 \text { to } \\
1.15\end{array}$ & $\begin{array}{c}-1.60 \text { to } \\
1.49\end{array}$ & $\begin{array}{l}0.90 \text { to } \\
1.09\end{array}$ & $\begin{array}{c}-1.45 \text { to } \\
0.34\end{array}$ & $\begin{array}{c}0.98 \text { to } \\
1.09\end{array}$ & $\begin{array}{c}-2.01 \text { to } \\
0.54\end{array}$ & $\begin{array}{c}0.97 \text { to } \\
1.12\end{array}$ & $\begin{array}{c}-1.07 \text { to } \\
0.74\end{array}$ & $\begin{array}{c}0.95 \text { to } \\
1.06\end{array}$ \\
\hline$\overline{G G T}$ & 0.47 & 1.00 & -0.23 & 1.01 & 0.22 & 1.00 & 0.44 & 0.99 & -0.15 & 1.01 & -0.95 & 1.02 & -0.78 & 1.01 \\
\hline$\overline{\text { GGT }}$ & $\begin{array}{c}0.12 \text { to } \\
0.83\end{array}$ & $\begin{array}{c}0.98 \text { to } \\
1.01\end{array}$ & $\begin{array}{c}-1.26 \text { to } \\
0.80\end{array}$ & $\begin{array}{c}0.99 \text { to } \\
1.03\end{array}$ & $\begin{array}{c}-0.22 \text { to } \\
0.65\end{array}$ & $\begin{array}{c}0.99 \text { to } \\
1.02\end{array}$ & $\begin{array}{c}-0.35 \text { to } \\
1.22\end{array}$ & $\begin{array}{c}0.97 \text { to } \\
1.01\end{array}$ & $\begin{array}{c}-1.00 \text { to } \\
0.70\end{array}$ & $\begin{array}{l}1.00 \text { to } \\
1.03\end{array}$ & $\begin{array}{c}-2.37 \text { to } \\
0.47\end{array}$ & $\begin{array}{l}1.00 \text { to } \\
1.05\end{array}$ & $\begin{array}{c}-2.53 \text { to } \\
0.96\end{array}$ & $\begin{array}{c}0.98 \text { to } \\
1.04\end{array}$ \\
\hline HCGbeta & 0.00 & 1.01 & -0.01 & 1.01 & 0.00 & 0.98 & 0.00 & 0.97 & 0.00 & 1.01 & 0.00 & 1.02 & 0.00 & 1.01 \\
\hline HCGbeta & $\begin{array}{c}-0.01 \text { to } \\
-0.00\end{array}$ & $\begin{array}{c}0.98 \text { to } \\
1.03\end{array}$ & $\begin{array}{c}-0.01 \text { to } \\
0.00\end{array}$ & $\begin{array}{c}0.97 \text { to } \\
1.05\end{array}$ & $\begin{array}{c}-0.01 \text { to } \\
0.00\end{array}$ & $\begin{array}{c}0.94 \text { to } \\
1.02\end{array}$ & $\begin{array}{c}0.00 \text { to } \\
0.01\end{array}$ & $\begin{array}{c}0.92 \text { to } \\
1.02\end{array}$ & $\begin{array}{c}-0.01 \text { to } \\
0.00\end{array}$ & $\begin{array}{c}0.97 \text { to } \\
1.04\end{array}$ & $\begin{array}{c}-0.01 \text { to } \\
0.00\end{array}$ & $\begin{array}{l}0.98 \text { to } \\
1.05\end{array}$ & $\begin{array}{c}0.00 \text { to } \\
0.00\end{array}$ & $\begin{array}{c}0.97 \text { to } \\
1.05\end{array}$ \\
\hline
\end{tabular}

In the second column from the left (headed 11:22), the triplicates of tubes ' 11 ' are compared with the triplicates of tube 22 . The constant bias (i.e. intercept) and its $95 \%$ confidence intervals $(\mathrm{Cl})$ as well as the proportional bias (i.e. slope) and its confidence interval are listed. The confidence intervals for the constant bias should include 0.00 , and that of proportional bias 1.00 , in order to prove the identity of the methods. The columns to the right contain identical data for comparison, 15 versus 10 min centrifugation, 15 versus 7 and 10 versus 7 min. Further to the right, the same comparisons were made for the '22'-tubes. The full list of comparisons is given as table $\mathrm{S} 1$ in additional files.

aberrations from the ideal values were minor in these cases, supporting the concept of pure randomness.

To further analyze the results, the distribution of the proportional biases that should randomly vary around the value 1.00 was studied (Figure 2). This analysis showed that 50 percent of all proportional bias (slopes) were located between 0.990 and 1.010 , and $99 \%$ of them were located between 0.924 and 1.086 . The extreme values were 0.90 and 1.15 . The parameters with proportional biases outside the $99 \%$ distribution and below 0.924 were the following: sodium, bicarbonate, $\mathrm{CKMB}$, and those above 1.086 were bicarbonate and CKMB. Apparently, the Deming fit did not appropriately estimate the slope in some of these outliers such as CKMB. From the scatter plot, we assume that relatively large variations in low normal values

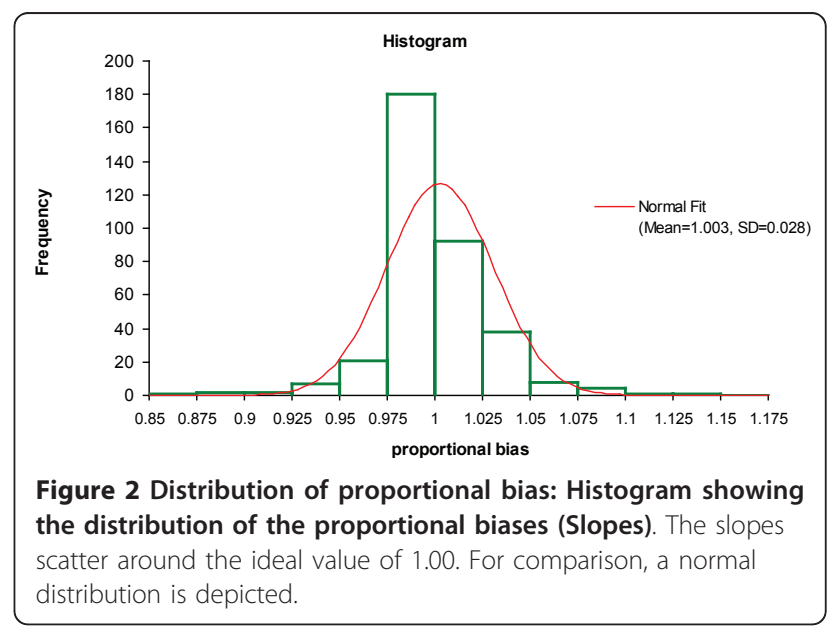


Table 3 Tests with confidence intervals of both proportional and constant bias exceeding the confidence interval and indicating a possible lack of identity between test and reference method.

\begin{tabular}{|c|c|c|c|}
\hline Parameter & Condition & Constant bias & $\begin{array}{l}\text { Proportional } \\
\text { bias }\end{array}$ \\
\hline & Т 22; C $1:$ C 2 & 0.12 (0.06 to 0.18$)$ & 0.99 (0.98 to 0.99 ) \\
\hline Bilirubin total & T 11; C $2:$ C 3 & 0.24 (0.04 to 0.44$)$ & 0.96 (0.94 to 0.99 ) \\
\hline Calcium & $\mathrm{T} 11 ; \mathrm{C} 1: \mathrm{C} 3$ & $-0.18(-0.33$ to -0.02$)$ & 1.08 (1.01 to 1.15$)$ \\
\hline Folic acid & Т 22; C 2 : C 3 & $0.98(0.24$ to 1.72$)$ & 0.95 (0.91 to 0.99 ) \\
\hline Iron & T 22; C $1:$ C 3 & $-0.22(-0.43$ to -0.02$)$ & 1.02 (1.01 to 1.03$)$ \\
\hline Transferrin & T 22; C $2:$ C 3 & $-0.84(-1.67$ to -0.02$)$ & 1.04 (1.01 to 1.06$)$ \\
\hline
\end{tabular}

$\mathrm{T}$ : tube; C: centrifugation condition as listed under section 2: Patients, materials and methods.

influenced this estimate. In others, like bicarbonate or sodium, the analytical imprecision combined with a small measurement range resulted in aberration from the $95 \%$ confidence interval.

As the values of the constant biases (intercepts) depend on the measurement range of the analyte, no similar analysis could be performed. Instead, we analyzed whether deviations accumulate in a certain centrifugation condition. The $95 \%$ confidence interval of the constant bias did not include the ideal 0.00 value 18 times, namely in comparison between tube 11 and tube 22: twice; in tube 11 - between centrifugation condition 1 and 2: once; between condition 1 and 3: 3 times; between condition 2 and 3: 3 times; in tube 22 between centrifugation condition 1 and 2: 4 times; between condition 1 and 3: twice and between condition 2 and 3: 3 times. Thus, the aberrant values did not cluster under any centrifugation condition.

In six instances, both constant and proportional bias confidence intervals did not include the ideal value. These tests were therefore considered as potentially significantly aberrant. These conditions were listed in table 3 . In all but one case, condition 3 was involved as test method, whereby either condition 1 or 2 were reference. As in all instances, the confidence intervals of the proportional bias and constant bias did not include the ideal values only marginally, we concluded that these outliers were generated only by chance. In order to enable the readers to make his or her own adjudgment on the significance of these deviations, the scatter plots of all six conditions including the slopes, their confidence intervals, the identity lines and the upper and lower limits of reference where appropriate, are displayed in Figure 3.

The procedure that has been discussed so far, calculates the probability of identity between the test method and the reference method (alpha error). For the purpose of this study however, the probability of a deviation between the two methods i.e. the beta error, is at least as relevant as the alpha error. The use of patient samples with a sufficiently large measurement range thereby enforced the statistical power.

The first estimate of the beta error according to the description in paragraph 2.4.2 is listed per parameter in table 1. All parameters except for chloride were below the allowable limits of the bias, the problem in chloride being the physiologically narrow range of sample values. Second, it was tested whether a specified bias could be detected at the limits of the reference values. As illustrated in Figure 1, a bias, named allowable bias on the figure, was pre-specified and the probability calculated that such a bias could be detected. In this example, the upper limit of reference is $41 \mathrm{U} / \mathrm{L}$. Five percent of 41 are 2.1 indicated on the figure as bias goal. The bias calculated from the data corresponds to 0.2 , which is much smaller than 2.1. The null hypothesis that the bias is equal or larger than the bias goal can be falsified with high probability, which excludes a deviation with high probability.

An illustrative sample of the 539 reference limits tested is given in table 4 and the full information is listed in additional file 2, table S2. $88.9 \%$ or 479 of those tests would detect a $5 \%$ bias. Interestingly, chloride was within this group. If the allowable bias was set to $10 \%$, $20 \%, 30 \%$ and $40 \%$, such biases would be excluded at further $48,8,3$, and 1 reference limits, respectively. These figures correspond to a cumulative frequency of $97.8 \%, 99.2 \%, 99.8 \%$ and $100 \%$ of all levels tested. The cortisol test required the highest allowable biases of all tests for falsifying the null hypothesis, namely, once $40 \%$, three times $30 \%$, twice $20 \%$ and once $10 \%$. This indicates that the number of specimens tested were insufficient for cortisol to exclude a bias with sufficient certainty.

We conclude that the conditions used including the number of measurements, the analytical range and the analytical imprecision were sufficient to detect a beta error with sufficient probability.

\section{Discussion}

Our study shows that the three centrifugation conditions tested deliver identical results. Moreover, the statistical power was sufficient to exclude any major deviation with a high probability. As mentioned before, very few studies on the influence of different centrifugation conditions on laboratory test results have so far been published [1-3]. In addition, a number of unpublished investigations were made available to us by the manufacturers of tubes or reagents. Our study results do not contradict any of those studies, but rather, they extent both the number of parameters and the test ranges. The number of samples and the spectrum of 

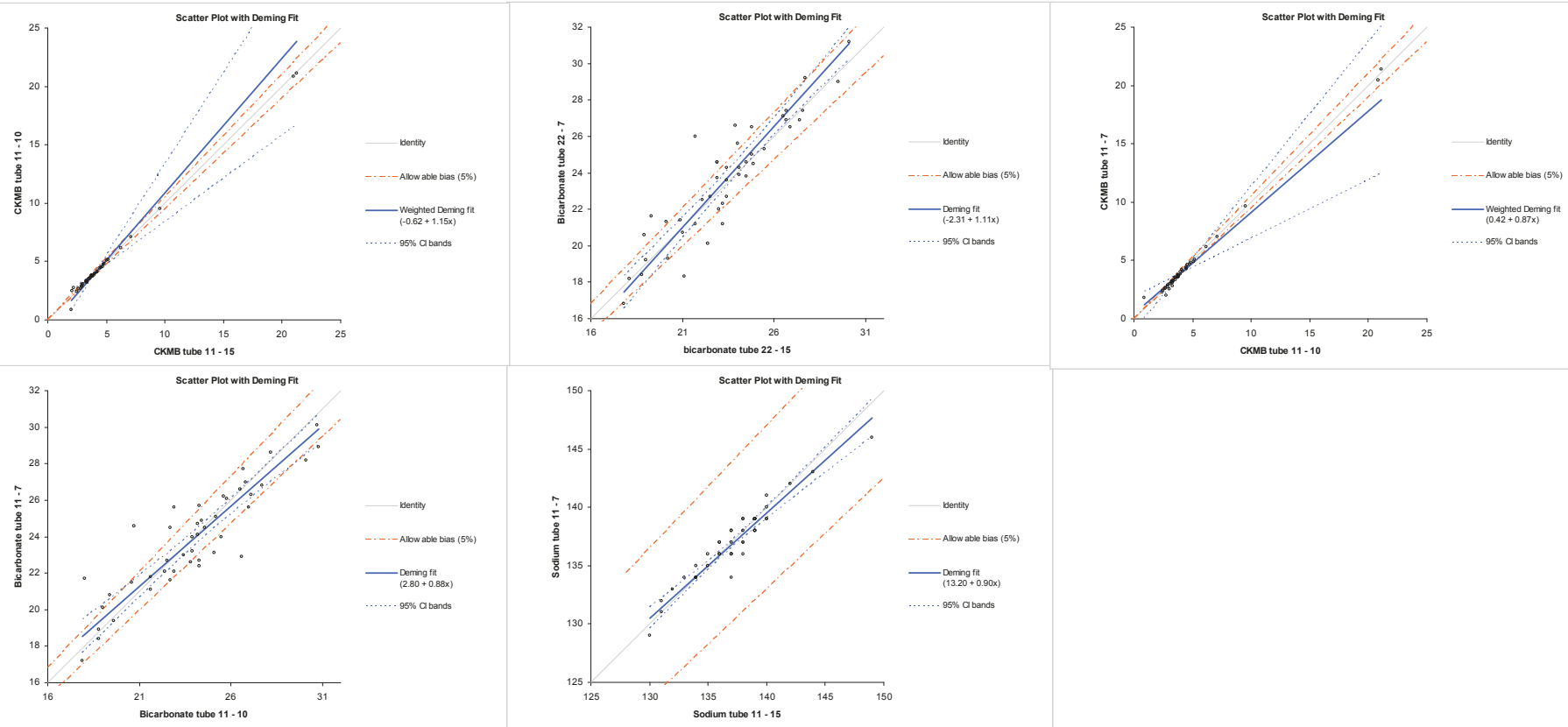

Group B: 95\% confidence interval of both proportional and constant bias do not include ideal values
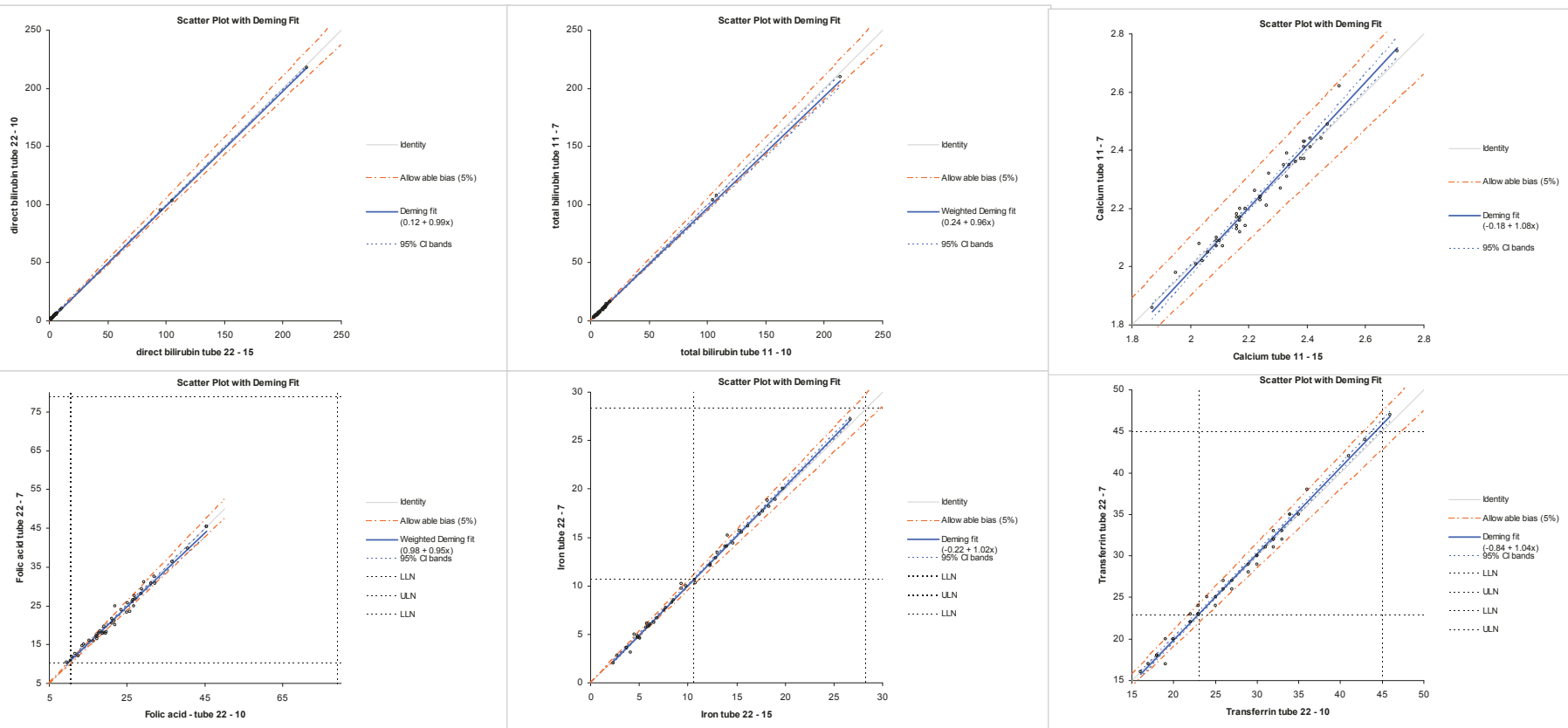

Figure 3 The scatter plots of the Deming fits mostly aberrant from identity are depicted. The upper five diagrams (group A) show those tests with a proportional bias outside the $99 \%$ distribution range (s. figure 2). The lower six diagrams (group B) show tests of which both proportional and constant bias did not indicate identity between the test and the reference method, as listed in table 3. 
Table 4 Excerpt of a list of the probabilities to detect a $5 \%$ bias with $95 \%$ certainty at the limits of the reference ranges limited to the comparison of tubes 11 to tubes 22.

\begin{tabular}{|c|c|c|c|c|c|c|c|c|c|c|c|c|c|}
\hline \multirow[b]{2}{*}{ Analyse } & \multirow[b]{2}{*}{ Ref. limits } & \multirow[b]{2}{*}{ Bias } & \multicolumn{2}{|c|}{$11: 22$} & \multirow[b]{2}{*}{ Bias Goal } & \multirow[b]{2}{*}{$p$} & \multirow[b]{2}{*}{ Analyse } & \multirow[b]{2}{*}{ Ref. limits } & \multirow[b]{2}{*}{ Bias } & \multicolumn{2}{|c|}{$11: 22$} & \multirow[b]{2}{*}{ Bias Goal } & \multirow[b]{2}{*}{$p$} \\
\hline & & & $95 \% \mathrm{Cl}$ & SE & & & & & & $95 \% \mathrm{Cl}$ & SE & & \\
\hline Alb & 35 & 0.3 & 0.0 to 0.5 & 0.12 & 1.8 & $<0.0001$ & $\mathrm{HDL}$ & 0.9 & 0.0 & 0.0 to 0.0 & 0.00 & 0.0 & $<0.0001$ \\
\hline Alb & 58 & 1.6 & -0.1 to 3.3 & 0.85 & 2.9 & 0.0683 & Iron & 10.6 & 0.1 & 0.0 to 0.2 & 0.05 & 0.5 & $<0.0001$ \\
\hline AP & 117 & 0.5 & -0.3 to 1.2 & 0.39 & 5.9 & $<0.0001$ & Iron & 28.3 & 0.4 & 0.1 to 0.8 & 0.17 & 1.4 & $<0.0001$ \\
\hline ALTL & 41 & 0.2 & -0.1 to 0.6 & 0.19 & 2.1 & $<0.0001$ & K & 3.5 & 0.0 & 0.0 to 0.1 & 0.01 & 0.2 & $<0.0001$ \\
\hline Amy-P & 53 & 0.0 & -0.4 to 0.5 & 0.23 & 2.7 & $<0.0001$ & K & 4.5 & 0.0 & 0.0 to 0.1 & 0.03 & 0.2 & $<0.0001$ \\
\hline Amyl & 100 & 1.0 & 0.3 to 1.7 & 0.35 & 5.0 & $<0.0001$ & $\mathrm{LDH}$ & 288 & 10.1 & 0.9 to 19.3 & 4.56 & 14.4 & 0.1746 \\
\hline ASTL & 37 & 0.2 & -0.2 to 0.6 & 0.19 & 1.9 & $<0.0001$ & LDL & 3.9 & 0.1 & 0.0 to 0.2 & 0.04 & 0.2 & 0.0019 \\
\hline Bili-D & 2 & 0.0 & 0.0 to 0.1 & 0.03 & 0.1 & 0.0039 & Lipe & 60 & 0.5 & 0.0 to 1.1 & 0.28 & 3.0 & $<0.0001$ \\
\hline Bili-T & 20 & 0.0 & -0.2 to 0.3 & 0.13 & 1.0 & $<0.0001$ & $\mathrm{Mg}$ & 0.75 & 0.0 & 0.0 to 0.0 & 0.00 & 0.0 & 0.0138 \\
\hline $\mathrm{Ca}$ & 2.02 & 0.0 & 0.0 to 0.0 & 0.01 & 0.1 & $<0.0001$ & $\mathrm{Mg}$ & 1.25 & 0.0 & 0.0 to 0.0 & 0.01 & 0.1 & $<0.0001$ \\
\hline $\mathrm{Ca}$ & 2.6 & 0.0 & 0.0 to 0.0 & 0.01 & 0.1 & $<0.0001$ & Myo & 28 & 0.2 & -0.2 to 0.5 & 0.16 & 1.4 & $<0.0001$ \\
\hline $\mathrm{CHE}$ & 3000 & -7.7 & -61.1 to 45.7 & 26.47 & 150.0 & $<0.0001$ & Myo & 72 & -0.3 & -0.9 to 0.3 & 0.31 & 3.6 & $<0.0001$ \\
\hline CHE & 11000 & 132.0 & 8.9 to 255.0 & 60.99 & 550.0 & $<0.0001$ & $\mathrm{Na}$ & 135 & 0.1 & -0.2 to 0.3 & 0.13 & 6.8 & $<0.0001$ \\
\hline Chol & 3.1 & 0.0 & -0.1 to 0.0 & 0.03 & 0.2 & $<0.0001$ & $\mathrm{Na}$ & 145 & -0.5 & -1.2 to 0.2 & 0.34 & 7.3 & $<0.0001$ \\
\hline Chol & 6.5 & 0.1 & 0.0 to 0.2 & 0.07 & 0.3 & 0.0011 & Phos & 0.87 & 0.0 & 0.0 to 0.0 & 0.01 & 0.0 & $<0.0001$ \\
\hline CK & 195 & 0.8 & -0.9 to 2.5 & 0.82 & 9.8 & $<0.0001$ & Phos & 1.45 & 0.0 & 0.0 to 0.0 & 0.01 & 0.1 & $<0.0001$ \\
\hline CKMB & 4.94 & -0.1 & -0.2 to 0.0 & 0.04 & 0.2 & $<0.0001$ & Pro-BNP & 125 & 0.3 & -0.9 to 1.6 & 0.63 & 6.3 & $<0.0001$ \\
\hline $\mathrm{CO} 2$ & 22 & -0.1 & -0.4 to 0.1 & 0.11 & 1.1 & $<0.0001$ & PTH & 1.59 & 0.0 & -0.1 to 0.1 & 0.04 & 0.1 & 0.0435 \\
\hline $\mathrm{CO} 2$ & 29 & -0.4 & -0.7 to -0.0 & 0.17 & 1.5 & $<0.0001$ & PTH & 9.33 & -0.1 & -0.3 to -0.0 & 0.05 & 0.5 & $<0.0001$ \\
\hline Cort & 82 & 0.9 & -5.3 to 7.1 & 3.07 & 4.1 & 0.1509 & RubG & 10 & 0.0 & -0.4 to 0.4 & 0.19 & 0.5 & 0.0111 \\
\hline Cort & 958 & 0.3 & -10.4 to 10.9 & 5.27 & 47.9 & $<0.0001$ & $\mathrm{~T} 3$ & 1.3 & 0.0 & 0.0 to 0.0 & 0.01 & 0.1 & $<0.0001$ \\
\hline Crea & 59 & 0.1 & -0.4 to 0.7 & 0.29 & 3.0 & $<0.0001$ & $\mathrm{~T} 3$ & 3.1 & 0.0 & -0.1 to 0.1 & 0.05 & 0.2 & 0.0054 \\
\hline Crea & 104 & 0.0 & -0.5 to 0.4 & 0.23 & 5.2 & $<0.0001$ & TN-T & 0.01 & 0.0 & 0.0 to 0.0 & 0.00 & 0.0 & $<0.0001$ \\
\hline CRP & 10 & 0.1 & -0.1 to 0.2 & 0.08 & 0.5 & $<0.0001$ & TNT-hs & 0.014 & 0.0 & 0.0 to -0.0 & 0.00 & 0.0 & $<0.0001$ \\
\hline $\mathrm{Cl}$ & 97 & 0.1 & -0.3 to 0.5 & 0.18 & 4.9 & $<0.0001$ & ToxoG & 1 & 0.0 & 0.0 to 0.0 & 0.00 & 0.1 & $<0.0001$ \\
\hline $\mathrm{Cl}$ & 110 & 0.0 & -0.4 to 0.4 & 0.20 & 5.5 & $<0.0001$ & TP & 66 & 0.4 & 0.0 to 0.8 & 0.19 & 3.3 & $<0.0001$ \\
\hline Ferri & 30 & -0.1 & -0.4 to 0.2 & 0.15 & 1.5 & $<0.0001$ & $\mathrm{TP}$ & 87 & 0.8 & -0.4 to 2.0 & 0.59 & 4.4 & $<0.0001$ \\
\hline Ferri & 400 & 2.7 & -0.9 to 6.2 & 1.77 & 20.0 & $<0.0001$ & Trigl & 2.3 & 0.0 & 0.0 to 0.0 & 0.01 & 0.1 & $<0.0001$ \\
\hline Fol & 10.4 & -0.1 & -0.6 to 0.4 & 0.24 & 0.5 & 0.0484 & Trfe & 23 & 0.1 & -0.1 to 0.3 & 0.09 & 1.2 & $<0.0001$ \\
\hline Fol & 78.9 & 1.6 & -0.9 to 4.1 & 1.25 & 3.9 & 0.0343 & Trfe & 45 & 1.0 & -0.2 to 2.3 & 0.62 & 2.3 & 0.0273 \\
\hline FT3 & 3.1 & 0.0 & 0.0 to 0.1 & 0.02 & 0.2 & $<0.0001$ & $\mathrm{TSH}$ & 0.34 & 0.0 & 0.0 to 0.0 & 0.01 & 0.0 & 0.0873 \\
\hline FT3 & 6.8 & -0.1 & -0.2 to 0.1 & 0.07 & 0.3 & 0.0003 & $\mathrm{TSH}$ & 5.6 & 0.0 & -0.1 to 0.1 & 0.05 & 0.3 & $<0.0001$ \\
\hline FT4 & 12 & 0.0 & -0.1 to 0.1 & 0.06 & 0.6 & $<0.0001$ & UA & 420 & 0.9 & -0.4 to 2.2 & 0.63 & 21.0 & $<0.0001$ \\
\hline FT4 & 22 & 0.2 & -0.1 to 0.4 & 0.11 & 1.1 & $<0.0001$ & Ureal & 3 & 0.0 & 0.0 to 0.0 & 0.01 & 0.2 & $<0.0001$ \\
\hline GGT & 49 & 0.2 & -0.1 to 0.6 & 0.18 & 2.5 & $<0.0001$ & Ureal & 8 & 0.0 & 0.0 to 0.0 & 0.01 & 0.4 & $<0.0001$ \\
\hline Gluc & 3.9 & 0.0 & -0.1 to 0.1 & 0.06 & 0.2 & 0.0029 & VitB12 & 133 & 1.8 & -2.5 to 6.1 & 2.15 & 6.7 & 0.0144 \\
\hline Gluc & 5.8 & 0.0 & 0.0 to 0.1 & 0.04 & 0.3 & $<0.0001$ & VitB12 & 675 & 0.8 & -7.7 to 9.3 & 4.20 & 33.8 & $<0.0001$ \\
\hline HAV & 20 & 0.0 & -0.1 to 0.1 & 0.04 & 1.0 & $<0.0001$ & VitD & 75 & 0.6 & -1.0 to 2.3 & 0.80 & 3.8 & 0.0002 \\
\hline HCGbeta & 2 & 0.0 & 0.0 to 0.1 & 0.02 & 0.1 & 0.0002 & & & & & & & \\
\hline
\end{tabular}

Those conditions not sensitive enough to detect a $5 \%$ bias were retested for a 10, 20, 30 or $40 \%$ bias (data not shown). The column heading Ref. limits means limits of reference ranges. At these concentrations of the analyte, the probability was tested to detect a $5 \%$ bias. Bias: The calculated deviation of the Deming regression line and its $95 \%$ confidence intervals $(\mathrm{Cl})$ and the standard error are given. Bias goal corresponds to a $5 \%$ deviation of the Deming regression line from identity at the tested analyte concentration. The full information on all comparisons is given in supplemental Table S2.

tests were relatively small in all preceding studies and, as the samples mostly from healthy persons were analyzed, the measurement ranges were relatively narrow, which altogether resulted in a relatively large beta-error. However, no beta error was ever calculated in the previous studies despite its significance.
In this study, a total of 14690 data pairs of quantitative clinical chemistry and immunology tests, acquired by comparing six different conditions and three different centrifugation regimens, were analyzed in 357 Deming procedures. Most of the comparisons showed excellent reproducibility indicating that the different centrifugation 
conditions used did not affect the outcome of laboratory testing. The percentage of statistical tests outside the $95 \%$ confidence limits was below the number expected for random variations. Corrections of the $\mathrm{p}$-values for multiple testing could be performed, such as the Bonferroni corrections. However, such procedure would increase the betaerror that, in our opinion, is at least as informative as the alpha-error for the purpose of our study. We preferred to analyze those outlier data to see whether they show any evidence of significant bias, and found evidence of random aberration rather than any statistical significant bias. The only way to ascertain our conclusion on the randomness of outliers would be a repetitious examination under identical conditions to exclude or confirm those aberrant values. We believe that we have provided sufficient data to convince the readers on randomness of these outliers and that the three centrifugation conditions as well as the two different gel separators of Greiner Bio-One provided identical results on a Cobas 6000 system of Roche Diagnostics.

The beta errors calculated by two separate methods confirmed a sufficient power of our analyses to detect significant deviations. The first of the two methods relied on regulatory limits either from USA or from Switzerland supplemented with our clinical estimates. The second one tests the biases at the limits of reference values to see whether they exceed a pre-specified bias. The reference limits were chosen for this purpose, as they discriminate between "normal" and "pathological" values, and deviations at these limits would result in "falsely normal" or "falsely pathological" results.

In addition to the quantitative tests, data from 23 qualitative tests or quantitative tests with little or no measurable concentrations did not provide any discrepant results. However, these tests were not statistically evaluated.

\section{Conclusions}

Our study provided substantial evidences that the centrifugation condition from the WHO guideline, the conditions of $10 \mathrm{~min}$ centrifugation time at $2180 \mathrm{~g}$ and of $7 \mathrm{~min}$ at $1870 \mathrm{~g}$ were equally effective to the performance of the subsequent laboratory analyses. Each of these conditions can be applied to a broad range of clinical chemistry and immunology tests, provided that specified tubes and analytical conditions were used (see section 2). Laboratories that have been hitherto accommodating the WHO recommendations are now having the possibility of reducing their centrifugation time to less than half of the original amount and in turn, to reduce their overall TAT significantly. Those laboratories that so far are reluctant to switch from serum to heparinized plasma because of the prolonged centrifugation time, can now have a second thought.

\section{Additional material}

Additional file 1: (Table S1): Deming fit results from all analytical parameters and centrifugation conditions. The results are displayed as outlined in the legend to table 2 .

Additional file 2: (Table S2): Probabilities to detect a 5\% bias with $95 \%$ certainty at the limits of the reference ranges for all parameters and all centrifugation conditions (beta error). The results are displayed as outlined in the legend to table 4.

\section{Acknowledgements}

This work was supported by Greiner Bio-One and Roche Diagnostics. We thank Ms Tanja Feusi for the skilful technical assistance, the patients and the nursing staff of internal medical wards for their collaboration and Prof. X. Schneider-Yin for the linguistic corrections of the manuscript.

\section{Author details}

${ }^{1}$ Stadtspital Triemli, Central laboratory Birmensdorferstrasse $497 \mathrm{CH}-8063$ Zürich Switzerland. ${ }^{2}$ Stadtspital Triemli, Department for Internal Medicine Birmensdorferstrasse $497 \mathrm{CH}-8063$ Zürich Switzerland.

\section{Authors' contributions}

EIM designed the study and wrote the manuscript, AS organized and supervised the blood drawings on the wards, DM and PN participated in the design of the study, organized and supervised the sample centrifugation and analyses of the samples, KP collected the data and performed the statistical analyses. All authors read and approved the final manuscript.

\section{Competing interests}

The authors declare that they have no competing interests.

Received: 13 January 2011 Accepted: 10 May 2011

Published: 10 May 2011

\section{References}

1. Foster K, Datta P, Orswell M, Tasaico K, Alpert A, Bluestein B: Evaluation of a centrifuge with rapid turnaround time for the preparation of plasma samples for measurement of common STAT markers on the ACS: 180 system 1. Clin Lab 2000, 46:157-160.

2. Lippi G, Salvagno GL, Montagnana M, Guidi GC: Preparation of a Quality Sample: Effect of Centrifugation Time on Stat Clinical Chemistry Testing. Labmed 2007, 38:172-176.

3. Mensel B, Wenzel U, Roser M, Ludemann J, Nauck M: Considerably reduced centrifugation time without increased hemolysis: evaluation of the new BD Vacutainer SSTTMII Advance. Clin Chem 2007, 53:794-795.

4. Calam RR, Bessman JD, Ernst DJ, Smith S, Szamosi DI, Warunek DJ, Wiseman JD: Procedures for the handling and processing of blood specimens; approved guideline. Wayne USA: CLSI; 2004, HA18-A3. CLSI Guidelines;24(38).

5. Kiechle FL, Betson F, Blackeney J, Calam RR, Catalasan IM, Raj P, Sadek W, Smith SR, Tang YW, Tomazic-Allen S: Procedures for the handling and processing of blood specimens; approved guideline. Wayne USA: CLSI; 2010, HA18-A4-A3. CLSI Guidelines;30(10).

6. WHO: Use of anticoagulants in diagnostic laboratory investigations. WHO/DIL/LAB/99.1/Rev2. 2002.

7. Mengozzi G, Rossato D, Bertello C, Garrone C, Milan A, Pagni R, Veglio F, Mulatero P: Rapid cortisol assay during adrenal vein sampling in patients with primary aldosteronism. Clin Chem 2007, 53:1968-1971.

8. Johnson LR, Doherty G, Lairmore T, Moley JF, Brunt LM, Koenig J, Scott MG: Evaluation of the performance and clinical impact of a rapid intraoperative parathyroid hormone assay in conjunction with preoperative imaging and concise parathyroidectomy. Clin Chem 2001, 47:919-925.

9. Bowen RA, Chan Y, Cohen J, Rehak NN, Hortin GL, Csako G, Remaley AT: Effect of blood collection tubes on total triiodothyronine and other laboratory assays. Clin Chem 2005, 51:424-433.

10. 2011 [http://en.wikipedia.org/wiki/Deming_regression], (accessed 14. Feb.2011). 
11. Linnet K: Performance of Deming regression analysis in case of misspecified analytical error ratio in method comparison studies. Clin Chem 1998, 44:1024-1031.

12. Hartmann C, Smeyers-Verbeke S, Penninckx W, Massart DL: Detection of bias in a method comparison by regression analysis. Anal Chim Acta 1997, 338:19-40.

13. Health care financing Administration, Public Health Service: Medicare, Medicaid and CLIA Programs; Regulations Implementing the Clinical Laboratory Improvement Amendmets of 1988 (CLIA). Federal Registry 1992, 57:7002-7186.

14. Externe obligatorische Qualitätskontrolle. 2010 [http://www.qualab.ch/ CQE_2010_03_d.pdf], accessed 10.Aug.2010.

\section{Pre-publication history}

The pre-publication history for this paper can be accessed here: http://www.biomedcentral.com/1472-6890/11/6/prepub

doi:10.1186/1472-6890-11-6

Cite this article as: Minder et al.: Effects of different centrifugation conditions on clinical chemistry and Immunology test results. BMC Clinical Pathology 2011 11:6.

\section{Submit your next manuscript to BioMed Central} and take full advantage of:

- Convenient online submission

- Thorough peer review

- No space constraints or color figure charges

- Immediate publication on acceptance

- Inclusion in PubMed, CAS, Scopus and Google Scholar

- Research which is freely available for redistribution

Submit your manuscript at www.biomedcentral.com/submit 